\title{
Judicial leadership on the UK Supreme Court
}

\author{
Rosemary Hunter ${ }^{1 * \dagger}$ and Erika Rackley ${ }^{2 * \dagger}$ \\ ${ }^{1}$ School of Law, Queen Mary, University of London, London, UK and ${ }^{2}$ Birmingham Law School, University of Birmingham, \\ Birmingham, UK \\ *rosemary.hunter@qmul.ac.uk; e.rackley@bham.ac.uk
}

(Accepted 24 July 2017)

\begin{abstract}
This paper examines judicial leadership on the UK Supreme Court. It does not confine itself to the formal roles of the President and Deputy President. Rather, building on existing categories of judicial leadership, including administrative, jurisprudential and community leadership, it considers the contributions of all 12 Justices. In so doing, it provides a significant compilation of quantitative data on the activities of the Justices of the Supreme Court both on and off the bench from the the Court's inception in 2009 to the end of the 2014-2015 legal year. From this, we suggest that while a number of the Justices engaged in one or two broad forms of leadership - with Lady Hale in particular demonstrating a substantial degree of leadership across all three dimensions - at the other end of the spectrum, at least on the measures used in this paper, a significant minority did not. In the light of this, and the significant number of recent and forthcoming retirements from the Court, the paper concludes by considering the implications of our findings for the future of the Court. We argue that these retirements will result in gaps in both formal and informal judicial leadership, and it is vital that these gaps are filled by appointees who are capable of, and prepared to step up to, diverse and varied forms of judicial leadership.
\end{abstract}

Keywords: UK Supreme Court; Judicial Leadership; Lady Hale; Quantitative Research

\section{Introduction}

This paper examines judicial leadership on the UK Supreme Court, from the inception of the Court in 2009 to the end of the 2014-2015 legal year. In doing so, it does not confine itself to the formal roles of the President and Deputy President. ${ }^{1}$ While the President and Deputy President are formal leaders of the Court, all 12 members of the Supreme Court may be considered, in a broader sense, to be judicial leaders. In constituting the final court of appeal in the UK, they occupy a prominent public position at the apex of the judicial system, and as such represent the judiciary in the eyes of the public, the media and the legal profession. This is recognised, for example, in the criteria for appointment to the

\footnotetext{
${ }^{\dagger}$ We would like to thank Tina Martin for research assistance and Alan Paterson, Kate Malleson, Graham Gee, Brenda Hale and the journal's anonymous reviewers for their extremely helpful comments on earlier versions of this paper.

${ }^{1}$ Much of the literature on judicial leadership focuses on formal leaderships roles, typically that of Chief Justice, see eg D Danelski 'The influence of the Chief Justice in the decisional process of the Supreme Court' in S Goldman and A Sarat (eds) American Court Systems: Readings in Judicial Process and Behaviour (New York: WH Freeman \& Co Ltd, 1978) p 486; L Greenhouse 'How not to be Chief Justice: the apprenticeship of William H. Rehnquist' (2006) 154 Penn L Rev 1365; VA Hettinger, SA Lindquist and W Martinek 'The role and impact of Chief Judges on the United States Court of Appeals' (2003) 24 Just Sys J 91; G Gallas 'Judicial leadership excellence: a research prospectus' (1987) 12 Just Sys J 39; SL Haynie 'Leadership and consensus on the US Supreme Court' (1992) 54 Journal of Politics 1158; P McCormick 'Assessing leadership on the Supreme Court of Canada: towards a typology of Chief Justice performance' (1993) 4 Sup Ct L Rev 409; P McCormick 'Follow the leader: judicial power and judicial leadership on the Laskin Court, 1973-1984' (1998) 24 Queen's L J 237; CL Osterberg, ME Wetstein and CR Ducat 'Leaders, followers and outsiders: task and social leadership on the Canadian Supreme Court in the early nineties' (2004) 36 Polity 505; K Leakey 'The role of the Chief Justice in Commonwealth Africa', PhD thesis, Queen Mary University of London (2012).
}

(c) The Society of Legal Scholars 2018 
Supreme Court, which include exceptional intellectual ability and interest in the law, 'appreciation of the developing nature of the constitution and law in England, Scotland, Northern Ireland and Wales', and ' $[\mathrm{an}]$ ability to participate in the representational role of a Supreme Court Justice'. This paper therefore asks how the Justices of the UK Supreme Court act as leaders.

In answering this question, the paper makes two distinct contributions to the socio-legal literature on courts and judging. First, it seeks to expand the conceptions of judicial leadership, building on existing categories of administrative, jurisprudential and community leadership but applying them to encompass a broader range of judicial activities than have previously been considered. Secondly, it provides a significant compilation of quantitative data on the activities of the Justices of the Supreme Court both on and off the bench. Whereas long-running statistical studies of apex courts exist in other jurisdictions, this has not yet occurred in the UK. Our data may thus provide the impetus and a baseline for future research and analysis of this nature. ${ }^{3}$

The paper begins with a brief account of the dimensions of judicial leadership identified in the literature. We explain our reasons for focusing on the three dimensions of administrative, jurisprudential and community leadership and the methodology we adopted for measuring them in terms of decided cases and extrajudicial activities. We subsequently set out our findings on these measures, identifying which Supreme Court Justices emerged as leaders on the court within each category. On the basis of this analysis, it appears that while a number of Justices engaged in one or two broad forms of leadership, Lady Hale was exceptional in demonstrating a substantial degree of leadership across all three dimensions, while at the other end of the spectrum - at least on the measures used in this paper - a significant minority did not stand out on any dimension. In the light of this, and the significant number of recent and forthcoming retirements from the Court, the paper concludes by considering the implications of our findings for the future of the Court. We argue that these retirements will result in gaps in both formal and informal judicial leadership, and it is vital that these gaps are filled by appointees who are capable of, and prepared to step up to, diverse and varied forms of judicial leadership.

\section{Dimensions of judicial leadership}

The existing literature identifies four broad categories of judicial leadership. ${ }^{4}$ The language used to describe these categories varies, but for the purposes of our analysis we have termed them 'administrative leadership', 'jurisprudential leadership', 'social leadership' and 'community leadership'. There are clearly potential overlaps between these categories - particularly between administrative leadership and the other categories - which we identify in the course of the discussion and analysis. However, the categories are useful heuristically in considering the variety of ways in which judges may exercise leadership generally, as well as in considering variety within particular forms of leadership.

\section{Administrative leadership}

Administrative leadership encompasses judicial governance - the running of the judiciary as a whole and/or of a specific court - and managing and negotiating relationships with other branches of government (especially the Ministry of Justice) as well as with bodies like Her Majesty's Courts and

\footnotetext{
${ }^{2}$ UK Supreme Court, 'Information pack: vacancies for appointment as Deputy President of the Supreme Court [and] Justice of the Supreme Court' (December 2017), available at https://www.supremecourt.uk/docs/judicial-vacancies-2018information-pack.pdf.

${ }^{3}$ See eg the long-running statistical analyses of the US Supreme Court published annually in the Harvard Law Review (most recently, 'The statistics' (2017) 131 HLR 403) and of the Australian High Court by Lynch and Williams beginning in 2003 (most recently, A Lynch and G Williams 'The High Court on constitutional law: the 2016 and French Court statistics' (2017) 40 UNSWLJ 1468).

${ }^{4}$ See generally A Paterson The Law Lords (London: Macmillan, 1982); A Paterson Final Judgment: The Last Law Lords and the Supreme Court (Oxford: Hart Publishing, 2013); R Cornes 'Gains (and dangers of losses) in translation - the leadership function in the United Kingdom's Supreme Court, parameters and prospects' [2011] PL 509 (on the UK); and RT Shepard 'The changing nature of judicial leadership' (2009) 42 Ind L Rev 767; WF Murphy 'Courts as small groups' (1966) 79 HLR 1565 (on the US).
} 
Tribunals Service (HMCTS) and the Judicial Appointments Commission. ${ }^{5}$ Together, these aspects of administrative leadership involve taking responsibility for the 'overall health of the judicial institution and for its effectiveness in dispensing substantial justice in the society that relies on [it]'. ${ }^{6}$ This form of judicial leadership is thus about 'building stronger institutions and more effective systems of justice" rather than making case-law through decisions in individual matters. This dimension usually corresponds with formal leadership roles such as President and Deputy President of the Supreme Court, the Lord Chief Justice, Master of the Rolls, Heads of Division and Senior Presiding Judge. The President and Deputy President of the UK Supreme Court, for example, have specific administrative roles conferred by the Constitutional Reform Act 2005, including determining the composition of panels for permission to appeal and full hearings; ${ }^{8}$ requesting senior appellate judges and retired appellate judges to act on the Supreme Court; ${ }^{9}$ making the Court's rules; ${ }^{10}$ dealing with complaints and discipline; and sitting on appointment panels for new Supreme Court Justices. ${ }^{11}$

At the same time, however, it is clear that some elements of administrative leadership are undertaken by judges other than those with formal leadership roles. Indeed, it has been argued that it is the responsibility of every 'modern judge' to act as a 'guardian of our legal system' and ensure that it is fit for purpose. ${ }^{12}$ In the context of the Supreme Court, while all Justices have general responsibility for institution building and the protection of the administration of justice, others take on specific roles. Lord Kerr, for example, has chaired the joint UK Supreme Court (UKSC) and Judicial Committee of the Privy Council User group, and Lord Hodge has been a member, alongside the President and Deputy President, of the Court's Strategic Advisory Board. ${ }^{13}$

\section{Jurisprudential leadership}

Jurisprudential or 'thought' leadership refers to the influence of a given judge on the decisions or jurisprudence of the Court, in a specific area or more generally. In our view, jurisprudential leadership may encompass influence over time as well as persuasion in individual cases; that is, it may involve the development of a line of thought at odds with the Court's general position but which is nonetheless jurisprudentially important. Much of the existing literature, however, employs a narrower conception of jurisprudential leaders as the judges who 'bring others with them', who have dominant voices on the bench, and who are able to persuade others to their point of view. ${ }^{14}$ In this vein, Richard Cornes notes:

\footnotetext{
${ }^{5}$ There is a considerable amount of general leadership literature relevant to this role (but not relevant to this paper). See eg RM Stogdill and BM Bass Handbook of Leadership: A Survey of Theory and Research (New York: The Free Press, 1990); K Grint Leadership: Limits and Possibilities (Basingstoke: Palgrave Macmillan, 2005); JM Burns Leadership (London: Harper Collins, 2010); DV Day and J Antonakis (eds) The Nature of Leadership (London: Sage, 2nd edn, 2011); PG Northouse Leadership: Theory and Practice (London: Sage, 7th edn, 2015).

${ }^{6}$ Shepard, above n 4, p 767.

${ }^{7}$ Ibid.

${ }^{8}$ Constitutional Reform Act 2005 (CRA), s 42.

${ }^{9}$ CRA, ss $38-39$.

${ }^{10}$ CRA, s 45 .

${ }^{11}$ Originally both the President and Deputy President sat on the ad hoc appointment commissions for appointments to the Supreme Court. However, in response to concerns about the dominance of the Supreme Court leadership in appointments to the Court, the Constitutional Reform Act was amended in 2013 to specify simply that the commission must include 'at least one judge of the Court' (s 27, as amended by the Crime and Courts Act 2013, s 20 and Sch 13). It has not gone unnoticed that the removal of the Deputy President from a formal role in Supreme Court appointments coincided with the appointment of Lady Hale as Deputy President. In practice, the President continues to sit on selection commissions other than when his or her successor is being appointed, and retains significant influence in the appointments process through his or her position as chair of the panel, or in the selection of his or her nominee when he or she is not a member.

${ }^{12}$ Vos J cited with approval by Lord Carnwath in "Do judges use gavels?" The modern judge in myth and reality', lecture at the Judicial College, 16 January 2013.

${ }^{13}$ The Supreme Court Annual Report and Accounts 2015-2016 (2016) pp 42, 16.

${ }^{14}$ See eg Lady Hale's discussion of Lord Bingham's leadership style in B Hale 'A supreme judicial leader' in M Andenas and D Fairgrieve (eds) Tom Bingham and the Transformation of the Law: A Liber Amicorum (Oxford: Oxford University Press, 2009) p 209.
} 
on any collegial court there is always the potential for de facto leaders to emerge ... In relation to jurisprudential leadership a top court may contain judges who, while not holding one of the court's formal leadership roles (with its managerial prerogatives), nevertheless emerge either in discrete areas of case law, or vis à vis a 'block of the court', or perhaps even more expansively in the majority of cases, as the court's intellectual leader. ${ }^{15}$

Alan Paterson, adopting David Danelski, terms this 'task leadership', that is, the exercise of 'effective leadership concerning decisional outcomes', which may be a product of 'personality, esteem within the court, intelligence, technical competence and persuasive ability'. ${ }^{16}$ His two qualitative studies of the House of Lords and the Supreme Court - The Law Lords (1982) and Final Judgment (2013) - provide insights into how task leadership is achieved, through group orientation, tactics or lobbying, and the stages at which it may occur, during the hearing of the case, at the first conference after the hearing, or in the circulation of judgments. Notable jurisprudential or 'task' leaders in the UK, Cornes and Paterson suggest, have included Lords Reid, Diplock, Atkin, Wilberforce and, more recently, Lords Bingham and Dyson. ${ }^{17}$

There is clearly potential for overlap between formal administrative leadership and jurisprudential leadership, as possession of the formal role may provide a tactical advantage, or respect for the formal role may translate into informal powers of persuasion in decision making. This has certainly been observed in relation to the Chief Justice of the United States Supreme Court. ${ }^{18}$ Paterson suggests that this has been less the case in the House of Lords and UK Supreme Court, in part because the Presiding Law Lord or Justice traditionally speaks last at post-hearing conferences, whereas the US Chief Justice traditionally speaks first, and thus has greater opportunity for jurisprudential leadership. ${ }^{19}$ Speaking last does not necessarily reduce the scope for influence, however. For example, Lady Hale has said of Lord Bingham as Senior Law Lord in post-hearing conferences:

What he [Lord Bingham] does say will be hugely influential and may well persuade others to change their minds. It is not unknown to hear four views going one way, and then to hear Lord Bingham going the other way, after which the four eventually decide to come around to Lord Bingham's point of view. ${ }^{20}$

Nevertheless, both Hale and Paterson contend that Lord Bingham persuaded his colleagues not by virtue of his role as Senior Law Lord but by 'the sheer force of his intellect and the clarity of his thinking. ${ }^{21}$ Paterson also maintains that Lords Phillips and Hope enjoyed mixed success as jurisprudential leaders. ${ }^{22}$

\section{Social leadership}

Social leadership, a category identified by Danelski, ${ }^{23}$ is focused on the collegial and emotional needs of the Court. Social leaders endeavour to keep the Court socially cohesive despite the inevitable conflicts which arise when important issues are at stake. ${ }^{24}$ They are likely to have 'warm, receptive and responsive' personalities and to be among the best liked members of the Court. ${ }^{25}$ For example,

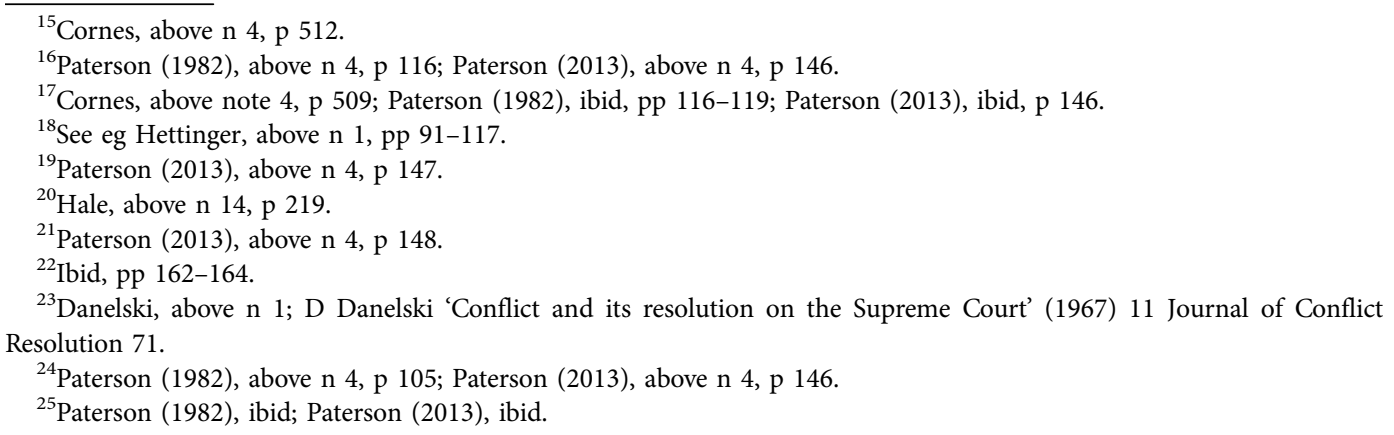


Paterson describes Lord Brown as the social leader of the House of Lords during the Bingham era. His office was strategically located near the secretaries' office and the coffee machine in the Law Lords' corridor. As a result, everyone came past his office, and he encouraged his colleagues to drop in so that his office became the Court's social centre. Interestingly, after the move to the new Supreme Court building, although Lord Brown's personality (we assume) did not change, his strategic geographical position did. His office was more isolated and did not provide the same opportunities for frequent interaction with colleagues, resulting in a considerably reduced role as social mediator. ${ }^{26}$

\section{Community leadership}

Finally, we use the term 'community leadership' to refer to the various ways in which judges engage in outreach work to the Court's various communities, including the general public, the legal profession, academia (including law students), the devolved jurisdictions and international judiciaries. This kind of extrajudicial work - described by Cornes as 'judicial statespersonship ${ }^{27}$ - helps to instil public and professional confidence in the Court, reinforces its accessibility and openness, and expresses a commitment to judicial institution-building at the broadest level. ${ }^{28}$ It also provides what in academia would be called 'esteem indicators' - that is, indications of the individual judge's profile beyond the Court and the extent to which they are in demand as a speaker. Since its inception the Supreme Court's Annual Reports have detailed many of the Justices' extracurricular activities, including overseas visits, educational visits, special events and media engagement.

Community leadership also includes what Peter McCormick terms 'academic leadership', that is, an influence extending beyond Court decisions to academic thinking about doctrinal development. ${ }^{29}$ This form of judicial leadership is not unproblematic. While, of course, the views expressed by superior court judges in an academic paper do not constitute precedent, ignoring them may, for example, result in significant additional costs for the litigants consequent upon a successful appeal. This may in turn lead to undue weight being attached to the views expressed by a superior court judge in such writings by counsel and even lower court judges who feel compelled to shape their arguments or judgments accordingly. ${ }^{30}$

To the extent that judicial speeches and academic publications on doctrinal subjects contribute to the development of the law, they may also constitute a form of jurisprudential leadership. On the whole, however, extrajudicial speeches and publications address a range of topics and are delivered to and published in a great variety of audiences and venues - specialist or generalist, academic or practitioner, scholarly journals, textbooks or practice manuals. In this paper, we have chosen to treat all extrajudicial speeches and publications under the heading of 'community leadership' rather than attempting to distinguish between those which may count as jurisprudentially versus community oriented.

\section{Observing judicial leadership}

The different forms of judicial leadership identified above may not all be performed by the same judges. As Paterson has clearly identified, those with formal administrative leadership roles are not necessarily also jurisprudential leaders or social leaders of the Court. Likewise, jurisprudential leaders on the Court may not all be able or willing to travel regularly to outside speaking engagements.

\footnotetext{
${ }^{26}$ Paterson (2013), ibid, pp 157, 166-168.

${ }^{27}$ Cornes, above n 4, pp 537ff.

${ }^{28}$ Also seen in publication of its Annual Report, the introduction of press summaries of decisions, and accessibility of its website. See further R Cornes 'A constitutional disaster in the making? The communications challenge facing the United Kingdom's Supreme Court' [2013] PL 266; Cornes, above n 4; and, in a US context, KM Esterling 'Public outreach: the cornerstone of judicial independence' (1998-1999) 82 Judicature 112.

${ }^{29} \mathrm{P}$ McCormick 'Judges, journals and exegesis: judicial leadership and academic scholarship' (1996) 45 UNBLJ 139.

${ }^{30}$ Ibid, pp 141-143.
} 
Moreover, some forms of leadership are more readily observable than others. While jurisprudential leadership may be discerned from an analysis of decided cases, many of the tasks of administrative leadership are performed behind closed doors, with only those directly relating to administrative leadership of the Court's adjudicative functions likely to be observable. Similarly, social leadership is likely to be known only to 'insiders', or to someone who has closely observed and/or interviewed members of the Court. ${ }^{31}$ Finally, though various indicia of community leadership - such as speeches to various audiences published on the Court's website, or instances of liaison with overseas judiciaries published in the Supreme Court's Annual Report - may be observed, these are limited to those of which there is a public record.

In the following section we describe the methodology we adopted in our study of leadership on the UK Supreme Court. This methodology was empirical and quantitative, using only publicly available data accessed primarily via the Court's website. Our reasons for adopting this methodology were twofold. First, it is important to understand how the Supreme Court Justices appear to outside observers. Consequently, we have based our analysis on the freely available information about the Justices' activities to which the media, the public, law students and most members of the legal profession have access. Secondly, our methodology is replicable. Other scholars are able - and indeed invited - to reproduce, update and engage with our results. They are not reliant on exclusive access to inside or restricted information on the workings of the Court.

The limitation of this approach is that our account cannot claim to be comprehensive. We have not, for example, been able to observe 'behind the scenes' forms of leadership such as social leadership and inter-institutional aspects of administrative leadership. Rather, the paper focuses on the dimensions of leadership which are quantifiable and empirically observable to members of the Court's various publics, that is, administrative leadership of the Court's adjudicative functions, jurisprudential leadership and community leadership. The benefit of this approach is that it is more open to debate and less reliant on self-reporting than 'trusted insider' accounts such as Paterson's. ${ }^{32}$ Statistics do not, however, speak for themselves, but must be interpreted, and we have drawn on the existing qualitative research in interpreting our data. Thus, we would argue that both quantitative and qualitative approaches yield important insights and are complementary. At the same time, we acknowledge that alternative interpretations of our data may be available and we hope our analysis will provoke discussion and debate in this regard.

\section{Methodology}

Our primary method was to undertake a systematic analysis of all decisions issued by the Supreme Court in the six-year period between its inception in October 2009 and the end of the 2014-2015 judicial year. This amounted to a total of 402 decisions. The last decision included in the dataset was $R$ (on the application of Tigere) $v$ Secretary of State for Business, Innovation and Skills. ${ }^{33}$ Each decision was coded for a range of variables including the date, number and identity of the Justices sitting on the case, the overall outcome, the jurisdiction and area(s) of law involved, which Justice presided, and the result reached and type of judgment written by each of the Justices. These data for each decision were entered into an SPSS database and analysed using frequencies and cross-tabulations. Where the numbers were sufficiently large to allow for meaningful analysis, associations between categorical variables were explored using chi-squared tests.

Since the literature on quantitative analysis of court decisions is not consistent, some explanation of the categories used in our coding scheme is required. First, we adopted the 'case' as our unit of analysis -

\footnotetext{
${ }^{31}$ Eg Paterson (1982), above n 4; Paterson (2013), above n 4; P Darbyshire Sitting in Judgment: The Working Lives of Judges (Oxford: Hart, 2011); G Gee, R Hazell, K Malleson and P O'Brien The Politics of Judicial Independence in the UK's Changing Constitution (Cambridge: Cambridge University Press, 2015). These methods too carry their own limitations, including the dangers of researcher capture and the reproduction of received wisdom, to which statistical analysis is relatively immune.

${ }^{32}$ Though we, of course, recognise and acknowledge that Paterson also includes statistical analysis in both his accounts.

${ }^{33} R$ (on the application of Tigere) $v$ Secretary of State for Business, Innovation and Skills [2015] UKSC 57.
} 
that is, each item with a separate medium-neutral citation number ([20XX] UKSC $n$ ) was counted as a single unit, regardless of the number of appeals that may have been conjoined within it. Some other long-running studies have counted individual appeals rather than cases, ${ }^{34}$ which would inflate the number of matters decided, but we have followed Paterson in counting cases rather than the number of appeals within them. As Paterson explains:

When it comes to calculating the rates at which judges dissent, or write judgments or concurrences the fairer approach appears to be to focus on 'cases' rather than 'appeals' because of the distorting effect that multiple appeals can have. Thus, if a Law Lord dissents on his own in a 'case' with five conjoined 'appeals', this will be counted as a single dissent, not five dissents. ${ }^{35}$

Secondly, we categorised the overall outcome of each case as either 'unanimous', 'single dissent', or 'split'. This meant either that all Justices agreed in the overall result (regardless of their reasons for doing so), or all but one of the Justices agreed with the result, or two or more of the Justices disagreed with the result. Again, this is consistent with Paterson ${ }^{36}$ but not with some other studies, which use the category 'unanimous' only when all members of the Court adopt the same reasons as well as the same result. ${ }^{37}$ Consistent with our definition of unanimity, we categorised Justices as being in the majority or minority when they agreed or disagreed with the overall result of the case (regardless of reasons for doing so). ${ }^{38}$ We also included a category of 'half-half, which applied in cases involving multiple appeals or multiple issues, when a Justice agreed with the majority result on some of the appeals or issues but disagreed on others.

Thirdly, we used multiple categories to describe the type of judgment delivered by each Justice in each case: read the Judgment of the Court, ${ }^{39}$ joined in the Judgment of the Court, single lead, joint lead, single concurrence, joint concurrence, single agreement, joint agreement, single dissent, joint dissent, single part concurrence-part dissent, or joint part concurrence-part dissent. A 'Judgment of the Court' is the name given to single unanimous judgments of the Supreme Court when no individual author or authors are identified. The judgment and/or the press summary issued by the Supreme Court usually makes clear, however, which Justice read the Judgment of the Court, and for analytical purposes we have taken this to be equivalent to authorship of a leading judgment. In all other types of judgment, 'single' denotes sole authorship, while 'joint' denotes multiple authorship (regardless of the number who joined in the judgment). A 'leading judgment', for our purposes, is a judgment which is clearly recognised as the lead by the other members of a unanimous Court, or by the majority where the Court is not unanimous. Such recognition may be in the form of simple agreements with that

\footnotetext{
${ }^{34}$ See eg A Lynch 'Dissent: towards a methodology for measuring judicial disagreement in the High Court of Australia' (2002) 24 Syd L Rev 470, p 502 and n 88, explaining the methodology used by the Harvard Law Review in its annual review of US Supreme Court decisions, which Lynch and Williams partially follow in their annual review of High Court of Australia decisions (see n 3). Lynch and Williams, however, count individual appeals only in cases involving multiple appeals in which all of the appeals are not decided uniformly.

${ }^{35}$ Paterson (2013), above n 4, p 14.

${ }^{36}$ Ibid.

${ }^{37}$ See eg Lynch, above n 34, p 479; A Lynch 'The Gleeson Court on constitutional law: an empirical analysis of its first five years' (2003) 26 UNSWLJ 32, p 39; MC Belleau and R. Johnson 'Judging gender: difference and dissent at the Supreme Court of Canada' (2008) 15 IJLP 57, p 58; T Poole and S Shah 'The Law Lords and human rights' (2011) 74 MLR 79, pp 85-86. Poole and Shah distinguish between cases which are 'unanimous' (involving a single set of reasons, either in a joint judgment or a leading judgment plus individual agreements) and those which are 'unanimous by concurrence' (involving a leading judgment plus one or more concurrences with the same result).

${ }^{38}$ Cf MC Belleau, R Johnson and C Vinters 'Voicing an opinion: authorship, collaboration and the judgments of Justice Bertha Wilson' (2008) 41 Sup Ct L Rev 53, p 56, in which 'majority' means reasons supported by a majority of judges, while 'plurality' means the situation where no set of reasons commanded a majority.

${ }^{39}$ In accordance with tradition, all Supreme Court judgments are delivered orally - often to a largely empty court - rather than simply being issued in written form. Thus the Justice who reads the Judgment of the Court is the one who delivers it orally.
} 
judgment, or concurrences which refer to that judgment and seek only to elaborate or offer differing reasons to a limited degree. Generally, the leading judgment is printed first and does the essential groundwork of explaining the facts, issues and arguments in the case; however, this is not invariably true as the groundwork may appear in a judgment whose reasoning and/or conclusions were not ultimately accepted by the majority, or may appear in more than one judgment. We adopted the coding rule that there could be only one leading judgment per case, and in some cases there was no leading judgment but only a series of concurrences with the overall or majority result.

We defined a 'concurrence' as a judgment which was not the leading judgment but which said something substantive about one or more of the issues involved, while arriving at the same result as the rest of the court or as the majority - in other words, the same result but for reasons that differed in some respect. ${ }^{40}$ By contrast with a concurrence, an 'agreement' was a simple statement that the Justice agreed with one or more of the other Justices without adding any reasoning of their own. The Justice(s) with whom they agreed could be either in the majority or the minority. A 'dissent' was a judgment which gave substantive reasons and disagreed with the result reached by the majority. A 'part concurrence-part dissent' was the kind of judgment written when the Justice took a 'half-half position on the result - that is, they gave reasons partly concurring with the majority result and partly dissenting from it. ${ }^{41}$

These definitions, while appearing straightforward, again differ from those used in some other studies. Some studies have not employed a separate category of agreement but have counted all agreements as concurrences. ${ }^{42}$ While this might simplify analysis, we consider there to be an important difference to be captured in distinguishing between concurrences and agreements, in terms of willingness or felt need to articulate a different point of view and to write substantively. ${ }^{43}$ More importantly, some have taken a different approach to the dividing line between concurrence and dissent. Andrew Lynch and George Williams in their examination of the decisions of the High Court of Australia, for example, count as concurrences only those judgments which agree with the ultimate orders issued by the Court, and dissents those judgments which disagree with the final orders. ${ }^{44}$ Thus, for example, a judge who agreed with the overall result (in favour of the appellant or respondent) but who would have disposed of the case differently (for example, by remitting the case for rehearing by the lower court rather than by substituting the appeal court's own decision) would count as dissenting. Paterson includes in his category of dissents 'judgments which agree on the outcome favoured by the majority but whose reasoning is radically different from that of the majority', ${ }^{45}$ whereas we have counted these kinds of judgments as concurrences. Marie-Claire Belleau and Rebecca Johnson, whose focus is on dissenting judgments in the Supreme Court of Canada, also refer to 'disagreement through the form of a concurrence $^{46}$ and take concurrences to be 'a form of judicial dissent'. ${ }^{47}$

We rejected these other approaches for reasons of clarity, consistency and simplicity. Lynch and Williams' approach may lead to the counterintuitive result that the numerical majority of judgments could be counted as dissents. Paterson's approach inevitably introduces an element of subjective judgement in the determination that reasoning is 'radically different' from that of the majority, whereas the overall result constitutes a more objective dividing line and enabled us to avoid making

\footnotetext{
${ }^{40}$ We started out attempting to distinguish between brief and more substantial concurrences but abandoned the effort because the distinction proved unworkable in practice.

${ }^{41}$ By contrast, Poole and Shah, following the Harvard Law Review, would count these judgments as dissents (above n 37 , pp 84, 86).

${ }^{42}$ Eg Lynch, above n 34, p 481; Paterson (2013), above n 4, p 11. Cf Poole and Shah, above n 37, p 85 who, like us, distinguish between concurrences (involving substantive reasoning) and simple agreements, which they term 'I concur opinions'.

${ }^{43}$ See also Poole and Shah, ibid.

${ }^{44}$ Lynch, above n 34, pp 471-483, following the Harvard Law Review.

${ }^{45}$ Paterson (2013), above n 4, p 12.

${ }^{46}$ Belleau and Johnson, above n 37, p 60.

${ }^{47}$ Belleau et al, above n 38, p 64.
} 
judgements about the nature of the reasoning employed. Further, we considered language such as 'concurrence as a form of dissent' to be unhelpful and potentially confusing, although we discuss further below the various reasons why judges may choose to write concurrences.

In classifying the subject matter of cases we took an inclusive approach. Rather than trying to assign each case to a single or dominant area of law, we instead decided to reflect the reality that individual cases might fall within several areas of law, ${ }^{48}$ for example 'criminal procedure' and 'human rights', ${ }^{49}$ or 'employment law' and 'EU law,, ${ }^{50}$ or 'civil procedure', 'insolvency law' and 'property/land/equity. ${ }^{51}$ This meant that the total number of subjects was greater than the total number of cases. In addition, we grouped subjects together into the broad categories of Commercial, ${ }^{52}$ Criminal, $^{53}$ Human $^{54}$ and Public. ${ }^{55}$ Again, cases falling within two or more broad areas were placed in more than one category, for example Human and Public, or Human and Criminal. A relatively small number of cases were excluded altogether from these groupings: property/land/equity cases, which did not fall wholly or mainly into any of the four broad categories, and costs cases which we treated as sui generis.

In addition to our analysis of decisions, we reviewed the Supreme Court website as at the end of the 2014-2015 judicial year for information on extrajudicial speeches given by the Justices, and the Court's Annual Reports up to 2014-2015 for information on Justices' international visits. It must be acknowledged that neither of these sources is comprehensive. For example, overseas visits by individual Justices are listed separately in the Annual Reports, but the hosting of overseas visitors in the UK is not. The Supreme Court hosts a number of visits by international diplomats, ministers, lawyers and judges every year to establish or maintain links and exchange views on areas of law and good practice. However, it is not always clear from the Annual Reports whom they met when they were in the UK, making it impossible to attribute meetings consistently to individual Justices. This means that the picture of international outreach we have been able to glean is slightly unbalanced in favour of those Justices who are able and willing to travel, and may not include all international activities, although there is no reason to suspect any systematic exclusions from the Annual Reports. Further, the compilation of speeches on the Court's website is dependent on judicial willingness to notify the Court's information office and to have their speech posted online. ${ }^{56}$ Thus, it is not a full collection of all speeches given by all of the Justices. It is valuable, however, in giving an indication of the number and topics of speeches given by those Justices who are willing (or indeed keen) to publicise their speeches. Finally, we reviewed the Westlaw Legal Journals Index, the Hein Online database, the Index to Legal Periodicals, and the British Library catalogue up to February 2016 for books, book chapters and journal papers published by the Justices, both during their time on the Supreme Court and before and (where relevant) afterwards. We included in our review both professional and academic publications, and any kind of papers including case comments and book reviews. In addition to these activities, it should be noted that the Justices undertake many other external

\footnotetext{
${ }^{48}$ Our classification scheme comprised the following subjects: administrative law, civil procedure, company law, consumer law, contract/commercial law, constitutional law, criminal law, criminal procedure, discrimination law, employment law, environmental law, EU law, evidence, family law, housing law, human rights law, immigration/asylum law, insolvency law, intellectual property law, medical law, planning law, property/land/equity, tax law, tort law, welfare law, and 'other'. Subjects which appeared several times in the 'other' category included the Proceeds of Crime Act, insurance, counterterrorism, sentencing and costs.

${ }^{49} \mathrm{Eg} R v$ Horncastle and others [2009] UKSC 14

${ }^{50} \mathrm{Eg}$ British Airways plc $v$ Williams and others [2010] UKSC 16.

${ }^{51} \mathrm{Eg}$ Henderson $v$ Foxworth Investments Ltd and another [2014] UKSC 41.

${ }^{52}$ Comprising company, commercial, competition, consumer, contract, intellectual property, insolvency, insurance, restitution and tax law.

${ }^{53}$ Comprising counterterrorism, criminal law, criminal procedure, evidence, proceeds of crime and sentencing.

${ }^{54}$ Comprising discrimination, employment, family, habeas corpus, housing, human rights, immigration/asylum, medical, occupational health and safety, privacy, probate, professional regulation, tort and welfare law.

${ }^{55}$ Comprising administrative, constitutional, data protection, EU, environmental, FOI, international, planning and water law.

${ }^{56}$ Email from Ben Wilson, the UK Supreme Court's Head of Communications, to Erika Rackley, 14 September 2015.
} 
engagements such as visiting and speaking at schools and universities, professional gatherings, judging moots and so forth, which do not feature in the Annual Reports or on the website or lead to publications. Nevertheless, the information that is publicly available provides a valuable insight into the formal and informal leadership roles adopted by the Justices.

\section{Administrative leadership of the Court's adjudicative function}

As noted above, the President and Deputy President of the UK Supreme Court have particular functions in relation to the conduct of the Court's business, including approving the panels to sit on each case, presiding in cases, potentially allocating judgment-writing roles, and generally setting policies relating to the operation of the Court. ${ }^{57}$ They may also exercise a more persuasive influence over the Court's decisions by virtue of their formal leadership role. During the period covered by our study, the Court had three different leadership regimes, consisting of Lord Phillips and Lord Hope (2009-2012), Lord Neuberger and Lord Hope (2012-2013) and Lord Neuberger and Lady Hale (2013-2015). ${ }^{58}$ We began by investigating the effects of these different leadership regimes, followed by patterns of presiding among the four court leaders.

\section{Leadership regimes}

We first asked whether assuming a formal leadership role on the Court resulted in any change in the types of judgments delivered. Lady Hale was the only Justice for whom it was possible to test this question, since both Lord Phillips and Lord Hope were the President and Deputy President respectively during their entire tenure on the Supreme Court. And while Lord Neuberger did participate in several Supreme Court decisions before joining the Court as President in 2012, ${ }^{59}$ the number of judgments he delivered during this earlier period was too small to enable any meaningful comparison with his body of judgments after he became President. By contrast, Lady Hale delivered 137 judgments as a Justice and 79 as Deputy President up to the end of the 2014-2015 judicial year, enabling statistical comparisons to be made between the two groups of judgments.

There was no difference in the proportion of cases on which Lady Hale sat as a Justice and as Deputy President - she continued to sit on 54\% of cases which, as discussed below, was one of the highest proportions on the Court. However after she became Deputy President she was significantly more likely to give leading judgments (24\% single leads as Deputy President vs $11 \%$ single leads prior to becoming Deputy President), and was significantly less likely to dissent (3\% single dissents as Deputy President vs $8 \%$ single dissents prior to becoming Deputy President). ${ }^{60}$ This does suggest some form of

\footnotetext{
${ }^{57}$ The President and Deputy President are appointed through an open appointments process (as set out in the CRA ss 25-31 and Sch 8) rather than the roles simply being allocated to the two most senior Justices. It is relatively uncommon to find a formal position of Deputy President in common law jurisdictions (in contrast to European constitutional courts), though, of course, this does not prevent strong systems of seniority operating on these courts outside formal roles.

${ }^{58}$ It is notable that all of these formal leaders other than Lady Hale had previously held other formal judicial leadership roles. Lord Phillips was previously Lord Chief Justice, Lord Neuberger was Master of the Rolls and Lord Hope was Lord President of the Scottish judiciary. Lord Neuberger and Lady Hale of course continued as President and Deputy President of the Supreme Court beyond the period of our study to September 2017, when Lady Hale became President and Lord Mance became Deputy President.

${ }^{59}$ Lord Neuberger was a member of the panel in six of the UKSC decisions issued in 2009. Although these cases have UKSC citations and therefore fall within the parameters of our study, they were heard in July 2009, before the formal establishment of the Court, and therefore drew on the membership of the House of Lords. In addition, Lord Neuberger 'acted up' in four UKSC cases while he was Master of the Rolls.

${ }^{60}$ Chi-square $=26.820, \mathrm{df}=10, \mathrm{p}=.003$. The $\mathrm{p}$ value $(<.05)$ indicates that there was a statistically significant association between the independent and dependent variables (ie whether or not Hale was Deputy President and her proportion of single leads and dissents) rather than the difference being a product of random chance. As explained in the 'Methodology' section above, a 'single dissent' means a dissent written individually rather than written jointly with another Justice. It does not indicate whether the particular Justice dissented alone or the Court was split. In fact, there was no statistical difference between Lady Hale's propensity to dissent alone or with other Justices before and after she became Deputy President, although
} 
jurisprudential leadership effect following from the assumption of formal leadership in Lady Hale's case, in that she was more likely to take an authoritative role and more likely to have her views prevail as Deputy President. There were no differences in the types of cases coming before the Court or on which Hale sat which might account for this change. Further testing of this phenomenon will become possible with changes to the composition of the Court and the assignment of formal leadership roles to serving Justices (such as the recent appointment of Lord Mance as Deputy President). But in any event, it appears likely to be related at least to some extent to the opportunities offered to the presiding Justice, discussed below, although Lady Hale's leading judgments after she became Deputy President were as likely to be in cases in which she did not preside as in cases in which she did preside. ${ }^{61}$

Secondly, we asked whether there were any discernible patterns of difference in the overall behaviour of the Court between leadership regimes. One difference that emerged was that the Court was significantly less likely to sit as an enlarged panel of seven or nine Justices under Lord Neuberger (12\% of cases) than under Lord Phillips (26\% of cases).$^{62}$ Another was the practice in relation to Judgments of the Court. Lord Phillips as President promoted Judgments of the Court as part of his desire to foster a 'team' ethos among the Justices, ${ }^{63}$ and such judgments were significantly more likely to be delivered when he was President than they were after Lord Neuberger became President. Where the Court was unanimous, Lord Neuberger appeared rather to favour the more traditional practice of a single leading judgment with which the other members of the Court agreed. In relation to unanimity more generally, the Court was least likely to be unanimous when Lord Phillips was President (75\% of cases) and most likely to be unanimous under the Neuberger-Hope regime ( $82 \%$ of cases), with the Neuberger-Hale regime falling between the two but closer to the former ( $77 \%$ of cases). Even at its lowest, however, $75 \%$ of cases is a relatively high rate of unanimity for an apex court in a common law jurisdiction. ${ }^{64}$

Thirdly, we asked whether the Court leadership regime had any impact on the behaviour of individual Justices. It was again impossible to gauge this for those Justices who were members of the Court exclusively or almost exclusively during a single regime, that is, Lords Phillips, Saville, Rodger, Brown, Collins and Dyson (under Lord Phillips and Lord Hope), and Lords Hughes and Hodge (under Lord Neuberger and Lady Hale). For some Justices whose tenure on the Court spanned two or three regimes, differences in their judgments over time appeared to be explained by reference to increasing seniority. Changes in Lady Hale's judgments since she became Deputy President have been noted above. Lord Walker sat on fewer cases over time, as did Lord Mance and Lord Kerr. ${ }^{65}$ Conversely,

statistical analysis was made difficult by the small number of cases involved. In numerical terms, five of her 11 single dissents prior to become Deputy President were dissents with others, while both of her two single dissents after becoming Deputy President were dissents with others.

${ }^{61}$ Of the 20 leading judgments Lady Hale delivered as Deputy President, ten were in cases in which she was the presider and ten were in cases in which Lord Neuberger presided.

${ }^{62}$ The criteria to be used when considering whether more than five Justices should sit on a panel are set out on the Supreme Court's website, available at https://www.supremecourt.uk/procedures/panel-numbers-criteria.html. They are: If the Court is being asked to depart, or may decide to depart from a previous decision; a case of high constitutional importance; a case of great public importance; a case where a conflict between decisions in the House of Lords, Judicial Committee of the Privy Council and/or the Supreme Court has to be reconciled; or a case raising an important point in relation to the European Convention on Human Rights. It appears, however, that Lord Neuberger took a narrower view than Lord Phillips as to when an enlarged panel was justified - though, of course, subsequent to our study period, he presided in $R$ (on the application of Miller and another) $v$ Secretary of State for Exiting the European Union when the Court historically sat en banc for the first time. See also P Darbyshire 'The UK Supreme Court - is there anything left to think about?' (2015) 21 European Journal of Current Legal Issues pp 2-3.

${ }^{63}$ Paterson (2013), above n 4, pp 141, 160.

${ }^{64}$ Poole and Shah similarly show that the House of Lords was unanimous (on our definition) in $78 \%$ and $79 \%$ of their preand post-Human Rights Act samples, respectively: above n 37, p 87. By comparison, see Paterson (2013), above n 4, p 113, Table 3.7 which is labelled 'Comparative dissent rates' but in fact appears to show comparative unanimity rates. This shows the UK Supreme Court more likely to be unanimous than the US Supreme Court, the High Court of Australia and the Supreme Court of Canada.

${ }^{65}$ One possible explanation for these declines is that as Justices become more senior, they prefer to sit - and preside - in the Privy Council rather than sitting on the Supreme Court where they do not have the opportunity to preside. However, after 
all of the cases in which Lord Mance and Lord Kerr presided occurred under the Neuberger-Hale regime. Lord Mance wrote more single concurrences under Phillips-Hope but more single leads under Neuberger-Hope, and similarly, Lord Kerr wrote more single concurrences under PhillipsHope but more single leads under Neuberger-Hale. No differences between leadership regimes emerged for those Justices more recently appointed to the Supreme Court: Lords Reed, Carnwath and Toulson.

Differences appeared for two Justices which could not be explained by their own increasing seniority. Lord Clarke moved from more single concurrences and single agreements under Phillips-Hope to more joint concurrences and joint agreements under Neuberger-Hale. Interestingly, all of those joint concurrences were with Lord Neuberger and/or Lady Hale, and a high proportion of the joint agreements were either with Lord Neuberger and/or Lady Hale, or were in cases in which Lord Neuberger or Lady Hale wrote the leading judgment. Moreover, Lord Clarke sat on a significantly lower percentage of cases in his specialist area of contract/commercial law and a significantly higher percentage of cases in his non-specialist areas of housing, medical and welfare law under NeubergerHale than under Phillips-Hope. This may account for a greater inclination to join with other Justices rather than to write single concurrences. What is unknown is whether this change in the mix of cases on which he sat was a product of Lord Clarke's own choice, or that of Lord Neuberger and Lady Hale as presiding Justices (see further the discussions of presiding and specialisation below).

In cases in which the Court was not unanimous, Lord Wilson was significantly more likely to be in the majority under Phillips-Hope, but significantly more likely to be in the minority under Neuberger-Hale. This appeared to be related to the observed change in Lady Hale's judgments following her appointment as Deputy President. Lady Hale and Lord Wilson sit together relatively frequently, as they both specialise in family law and in our broad category of 'Human' cases. In total, Lady Hale and Lord Wilson sat together on 23 cases in which the Court was divided during our study period. In only six of those cases were they on the same side, and four of those six were decided under the leadership of Lords Phillips and Hope. It may be, therefore, that as Lady Hale assumed greater jurisprudential leadership within the Court, Lord Wilson's difference of view was more likely to consign him to a minority position.

\section{Presiding}

The presiding Justice is always the most senior Justice sitting on the case, who may be but is not necessarily the President or Deputy President. In fact, of the 402 cases in our database, only 37 (fewer than 10\%) had a Justice other than the current President or Deputy President presiding. ${ }^{66}$ Clearly, therefore, the practice on the Supreme Court is for the roles of President and Deputy President to include chairing the Court's hearing panels. The Justices other than the President and Deputy President who presided in the largest numbers of cases were Lord Walker in 11 cases and Lord Mance in nine cases. ${ }^{67}$ These cases have been excluded from the following analysis.

reviewing Privy Council cases from October 2009 to July 2015, this hypothesis proved not to be persuasive. During the period of our study the Privy Council decided 237 cases, with the Justices sitting on an average of $39 \%$ of the Privy Council cases decided during their tenure. Lord Walker sat on a lower than average proportion of Privy Council cases during the period; Lord Mance sat on a high proportion of Privy Council cases, but he did so uniformly since 2011; the number of Privy Council cases on which Lord Kerr sat fluctuated from year to year without any noticeable upward trajectory. Moreover, opportunities for presiding for more senior judges were not much more available on the Privy Council than on the Supreme Court. The President and Deputy President of the Supreme Court presided in the majority of Privy Council cases (Lord Phillips: 50, Lord Hope: 43, Lord Neuberger: 40, Lady Hale: 32). Lord Mance was the only Justice to preside in a significant number of cases outside this group (27). So while Lord Mance sat on a higher proportion of Privy Council than of Supreme Court cases, this was not always because of the opportunity to preside.

${ }^{66}$ The majority of these were from England and Wales, with only five from Scotland and two from Northern Ireland.

${ }^{67}$ As noted at $n 65$ above, the same pattern, albeit to a less extreme degree, prevailed in the Privy Council. In that Court, a Justice other than the President or Deputy President presided in 30\% of cases, with Lord Mance in the lead (27 cases), followed by Lords Rodger (12), Walker (10) and Kerr (10). 
Of the remaining 365 cases, Lord Phillips presided in 77, Lord Hope in 108, Lord Neuberger in 139 and Lady Hale in 41 . The number of cases in which Lady Hale presided is clearly much lower than those of her colleagues. This may be explained by the fact that Lords Phillips and Neuberger as President sat together with their Deputy President Lord Hope fairly rarely (in $12 \%$ and $13 \%$ of cases, respectively), with the result that Lord Hope presided in almost all the cases on which he sat. The same was not true, however, for Lord Neuberger and Lady Hale. Lord Neuberger as President sat with Lady Hale as Deputy President on over a quarter of the cases decided under their leadership (28\%), thus providing her with fewer opportunities to preside. As indicated above, this was not a function of the President and Deputy President tending to sit together on enlarged panels, since these occurred less often under Lord Neuberger than under Lord Phillips. In fact, both Lord Phillips and Lord Neuberger tended to sit with Lord Hope only on enlarged panels, while Lord Neuberger sat with Lady Hale both on enlarged panels and on panels composed of five Justices.

The opportunity or otherwise to preside is highly significant. In Final Appeal, Gavin Drewry and Louis Blom-Cooper wrote that 'The presiding judge (even in a judicial system founded on separate judgments) can exercise considerable influence over the course of argument presented to the Court, and may even play a disproportionate part in drafting the final decision' ${ }^{68}$ Indeed, Paterson suggests Lord Phillips thought that the President ought to write the lion's share of lead judgments. ${ }^{69}$ In fact, however, Lord Phillips wrote the lead judgment ${ }^{70}$ in only $30 \%$ of the cases in which he presided. It was Lord Hope who appeared to take the lion's share doctrine most seriously, writing the lead judgment in $42 \%$ of the cases in which he presided. This level of leading was not emulated by either Lord Neuberger (22\% leads when presiding) or Lady Hale (27\% leads when presiding). It does, however, appear that the view of the presiding judge as to the outcome of the case almost always prevails. Lord Phillips' dissent rate as presider was 3\%; Lord Neuberger's and Lady Hale's was just 2\%. Again, it was Lord Hope who exercised the greatest degree of control over outcomes. He was never in the minority in any of the cases in which he presided.

In terms of the ability to go one step further and produce unanimity as a presiding Justice, Lady Hale had the greatest success. The Court was unanimous in $69 \%$ of cases in which Lord Phillips presided, $74 \%$ of cases in which Lord Neuberger presided, $82 \%$ of cases in which Lord Hope presided, and $85 \%$ of cases in which Lady Hale presided. Although the number of cases in which Lord Phillips and Lord Neuberger did not preside was too small to enable statistical analysis, there was a statistically significant difference in the level of unanimity when both Lord Hope and Lady Hale were presiding compared to when they were not presiding. This may be explained, however, by the fact that the President presides in most cases with an enlarged panel, which by their nature (and statistically) are more likely to produce split decisions, whereas the Deputy President more often presides over regular panels of five Justices which are more likely to be unanimous.

Yet it is also notable that when Lady Hale wrote the leading judgment, the Court was more likely to be unanimous than when she did not write the leading judgment. This was not true for Lords Phillips, Hope or Neuberger. And indeed, this phenomenon held true throughout the entire period of the study, not only after Lady Hale became Deputy President. It might be hypothesised that when Lady Hale wrote the leading judgment it was likely to be in her specialist area of family law, and therefore the rest of the Court was more likely to defer to her expertise. But further analysis suggests this is not a convincing explanation. All four of the Court's Presidents and Deputy Presidents wrote a number of leading judgments in their specialist areas (for example, Lord Neuberger in intellectual property and property law more generally), all wrote leading judgments in human rights cases (the largest area of the Court's workload), and all wrote leading judgments outside their specialist areas. Overall, Lady Hale wrote leading judgments in 18 different subject areas, compared

\footnotetext{
${ }^{68} \mathrm{~L}$ Blom-Cooper and G Drewry Final Appeal - A Study of the House of Lords in its Judicial Capacity (Oxford: Clarendon Press, 1972) p 179.

${ }^{69}$ Paterson (2013), above n 4, p 160.

${ }^{70}$ 'Lead judgments' here is an aggregate of single leads, joint leads and reading the Judgment of the Court.
} 
to 19 for Lord Neuberger, 17 for Lord Hope, and nine for Lord Phillips. The unanimity effect when Lady Hale wrote the leading judgment does not appear, therefore, to be a function of her particular specialisation. It may reflect her desire, when writing a leading judgment, to seek consensus as far as possible, ${ }^{71}$ and therefore to make an effort to write judgments with which the other members of the court can agree.

The presider is also influential in determining the opportunities available to other Justices through selection of who writes the leading judgment. Lords Phillips and Hope chose who would write the leading judgment (or the Judgment of the Court) if it was not themselves, even if they were in the minority. ${ }^{72}$ The same remained true under the Neuberger-Hale regime, though Lord Neuberger has suggested that the decision was, at least in part, dictated by a desire to ensure that judgment writing was split equally between the Justices both in terms of quantity of judgments and judgments in interesting cases. ${ }^{73}$ We therefore looked to see whether there were any differences in the proportion of leading judgments written by other Justices according to who was presiding in the case, or any other differences by presider. In fact, very little emerged. Only three Justices wrote different proportions of leading judgments under different presiders - Lady Hale (more leads with Lord Hope than with Lord Phillips, and when she herself was presiding); Lord Kerr (more leads with Lords Hope and Neuberger than with Lord Phillips or Lady Hale); and Lord Clarke (more leads with Lord Phillips than with Lord Hope or Lady Hale). The identity of the presider appeared to make no difference to the proportion of leading judgments written by Lords Saville, Rodger, Walker, Brown, Collins, Reed, Toulson or Hodge. Where differences were found, they tended to relate not to the type of judgments written, but rather to whether the Justice sat on the Court at all.

Paterson explains that draft panels for cases are prepared by the Registrar of the Supreme Court, taking into account expertise and workload. These are then submitted to the President and Deputy President for approval. In general, Lords Phillips and Neuberger usually accepted the Registrar's suggestions, whereas Lord Hope made changes from time to time. ${ }^{74}$ Our data showed that when Lord Phillips was presiding, Lords Mance, Kerr, Clarke and Wilson were more likely to sit on the case. When Lord Hope was presiding, Lords Kerr and Carnwath were more likely to sit on the case, but Lady Hale and Lords Mance, Clarke and Sumption were less likely to do so. When Lord Neuberger presided, Lords Mance, Clarke and Sumption were more likely to sit on the case, but Lady Hale (by virtue of being Deputy President), Lord Kerr and Lord Wilson were less likely to do. When Lady Hale presided, Lords Wilson and Hughes were more likely to sit on the case, but Lords Clarke, Sumption and Carnwath were less likely to do so. The most likely explanation for these patterns lies in different judicial expertise and specialisation, in line with Paterson's account. Lord Neuberger, for example, tended broadly to preside in commercial cases while Lady Hale tended to preside in non-commercial cases. The issue of specialisation is discussed further below.

In summary, different leadership regimes made small but significant differences to judicial behaviour on the Supreme Court. Lady Hale was most likely to produce unanimity as a presider. She was also more likely to write the leading judgment and less likely to dissent after she became Deputy President. More generally, writing the leading judgment and having one's opinion of the outcome of the case prevail are prerogatives of the presider - a role most likely to be taken by the President or Deputy President. Lord Hope took the greatest advantage of these prerogatives, writing the leading judgment in almost half of the cases in which he presided, and never being in the minority in those cases. Moreover, Lord Hope was given greater opportunity to preside by both Lord Phillips and Lord Neuberger than was Lady Hale by Lord Neuberger.

With regard to the other Justices who served on the Court under the different leadership regimes, Lords Mance and Kerr gained greater opportunities over time to write leading judgments

\footnotetext{
${ }^{71}$ Paterson (2013), above n 4, p 135.

${ }^{72}$ Ibid, p 160.

${ }^{73}$ Lord Neuberger 'Tweaking the curial veil', The Blackstone Lecture 2014, Pembroke College, Oxford, 15 November 2014 [28].

${ }^{74}$ Paterson (2013), above n 4, p 72. See also Gee et al, above n 31, p 199.
} 
and to act as presider. The mix of cases on which Lord Clarke sat changed, which in turn produced a change from more individualist to more collective judgment writing. In cases in which the Court was not unanimous, Lord Wilson and Lady Hale tended to be on opposite sides, with the consequence that as Lady Hale moved over time from a more to a less frequent dissenter, Lord Wilson moved in the opposite direction.

\section{Jurisprudential leadership}

The existing literature tends to focus on the writing of leading judgments as the primary evidence of jurisprudential leadership. McCormick has gone further and investigated the writing of leading judgments in 'important' cases, with 'importance' being assessed by reference to the frequency with which those judgments are cited in the Court's subsequent decisions. ${ }^{75}$ In line with our concern to explore the multiple dimensions of judicial leadership, we have taken a more expansive view of jurisprudential leadership. First, since the UK Supreme Court (unlike other apex courts in the common law world) does not sit en banc, the sheer presence of a Justice on the panel and therefore contributing to judicial conversations in a high proportion of cases may constitute a form of leadership. Secondly, as well as leading judgments, the writing of concurrences and dissents may be seen as a form of jurisprudential leadership, as the Justice articulates alternative reasoning which represents a particular point of view and/or which may later be taken up by others. This point is elaborated below, but at this stage, rather than simply focusing on leading judgments, we are interested in the distinction between writing a substantive judgment and simple agreement. Thirdly, another form of jurisprudential leadership may be found in the fact of specialisation. ${ }^{76}$ Almost all Supreme Court Justices specialise in particular areas of law (Lady Hale and Lord Wilson in family law, Lords Mance and Sumption in commercial law, Lord Carnwath in environmental law, to name obvious examples), and thus they may distinguish themselves as 'thought' leaders in a specific area or areas of law rather than across the board. ${ }^{77}$ They may also specialise at a jurisdictional level (the Scottish and Northern Irish Justices, for example, although this is something that needs to be investigated rather than assumed). Alternatively, leadership may be evidenced by being a generalist rather than a specialist. In line with most of the literature, however, we assess jurisprudential leadership by reference to substantive decisions in appeals coming before the Court. ${ }^{78}$

\section{Sitting on cases}

By the end of our study period, Lady Hale had contributed to more Supreme Court decisions than any other serving or retired Supreme Court Justice. She participated in 216 of the 402 decisions issued by the Court during the period of our study. Lord Clarke participated in the next highest number of decisions: 176 (40 fewer than Lady Hale), while the remaining serving Justices appointed in the first tranche of appointments to the Supreme Court, Lords Mance and Kerr, participated in 156 decisions and 166 decisions, respectively. ${ }^{79}$

\footnotetext{
${ }^{75} \mathrm{P}$ McCormick 'Who writes? Gender and judgment assignment on the Supreme Court of Canada' (2013) 51 Osgoode Hall Law Journal 595.

${ }^{76} \mathrm{Cf}$ Lord Sumption's recently expressed view that 'legal specialisations are essentially bogus' and 'it is all just law': 'Family law at a distance', speech given at the 'At a Glance' Conference, Royal College of Surgeons, London, 8 June 2016.

${ }^{77}$ However, as Lord Sumption also notes, although ' $[t]$ here will usually be at least one specialist on the appeal panel ... his or her voice will not necessarily be decisive': ibid.

${ }^{78} \mathrm{~A}$ further way in which a Justice may exercise jurisprudential leadership is in influencing the nature of the Court's caseload through the granting (and refusal) of permissions to appeal (PTA). Analysis of permissions to appeal was beyond the scope of the current research. Chris Hanretty (Professor of Politics, Royal Holloway) has analysed PTA decisions but his work remains unpublished at the time of writing.

${ }^{79}$ It should be noted that the number of Supreme Court decisions in which a Justice participated is not necessarily an indicator of total workload. Supreme Court Justices also sit on the Privy Council. Lords Clarke (93), Mance (111) and Kerr (91) sat on more Privy Council cases than Lady Hale (69) during our study period. In addition, two Justices sit on the Court of Final Appeal in Hong Kong for up to a month each year. According to the Court's Annual Reports, during
} 
The ordering changes somewhat when allowance is made for the period of time spent on the Court. Here Lord Neuberger emerged at the top of the list, having participated in $64 \%$ of the decisions issued during his time on the Court. He was followed by Lord Brown (59\%, though only 94 decisions), Lord Hope (57\%) and then Lady Hale (54\%). Almost all of the remaining Justices participated in a similar proportion of decisions, around 44\%, with the exception of Lord Saville, whose duties on the Bloody Sunday Inquiry meant that he participated in only $22 \%$ of decisions during his time on the Court. ${ }^{80}$ Lord Neuberger's and Lord Hope's figures are clearly a reflection of their formal leadership roles on the Court, although it is notable that the same was not true for Lord Phillips, who participated in just $42 \%$ of the decisions issued during his time as President (a mere 77 decisions in total). ${ }^{81}$ Lady Hale's figures were not entirely due to her position as Deputy President, since she participated in the same high percentage of decisions throughout her time on the Court. The high figure for Lord Brown is less explicable. ${ }^{82}$ It may be that he was more available to sit than other Justices and/or was well liked as a panellist, possibly reflecting his social leadership role on the Court identified by Paterson.

\section{Types of judgments}

In terms of authorship of leading judgments, ${ }^{83}$ our data showed that Lord Hope and Lord Phillips took the role of the Court's intellectual leaders at the outset by virtue of their formal leadership positions. Lord Hope had the highest proportion of leading judgments of any Justice, authoring the leading judgment in 35\% of his cases, with Lord Phillips leading in 30\% of his cases. Among the other Justices, Lords Toulson and Sumption emerged with the highest proportions of leading judgments during the period of our study, writing the leading judgment in $26 \%$ and $25 \%$ of their cases, respectively. ${ }^{84}$ It is unsurprising that newer members of the Court should have higher proportions of leading judgments than more senior members, since the newer members spent more time on the Court under a leadership regime which gave them the opportunity to write leading judgments, rather than reserving that role largely to themselves. In this sense, Lord Neuberger as President and Lady Hale as Deputy President were more egalitarian in sharing leading judgments and therefore opened up possibilities for more junior members of the Court which were not previously available. ${ }^{85}$ The smallest proportions of leading judgments were given by Lord Rodger (8\%) and Lord Kerr (10\%). As will be seen below, these were the two Justices with the highest dissent rates. Elliot Slotnick has suggested that frequent dissenters are given fewer leads as 'an apparent implicit outsider tax'. ${ }^{86}$ This may well have occurred in the cases of Lords Rodger and Kerr. ${ }^{87}$

Opinion on the value and desirability of concurring judgments is divided. Those opposed to concurrences argue that they 'serve only to fudge areas of real agreement' and are 'insidious to ... clarity

the period of our study Lords Clarke, Walker and Neuberger undertook this role. However, our focus here is on the number of Supreme Court cases, as this is an indicator of presence and hence of some kind of influence on the Court which determines the law of the UK.

${ }^{80}$ Lord Brown also sat on the highest proportion of Privy Council cases during our study period (58\%). Other Justices sitting on higher than average proportions of Privy Council cases were Lords Toulson, Mance, Wilson, Dyson, Sumption and Hodge. By contrast, Lord Hope sat on $28 \%$ of Privy Council cases and Lady Hale sat on $29 \%$.

${ }^{81}$ In this context, it is interesting to note that while Lord Hope and Lord Neuberger sat on a much lower proportion of Privy Council cases (28\% and 35\%, respectively) than of Supreme Court cases, Lord Phillips sat on similar proportions of cases on both courts ( $41 \%$ of Privy Council cases).

${ }^{82}$ And even less explicable considering that, as noted above ( $\mathrm{80}$ ), he also sat on the highest proportion of Privy Council cases.

${ }^{83}$ As noted earlier, this includes both single leads and reading the Judgment of the Court.

${ }^{84}$ Lord Toulson also wrote a high proportion of leading judgments in the Privy Council (29\%), although Lord Sumption's proportion of leading judgments in the Privy Council was much lower (13\%).

${ }^{85}$ As noted by Lord Neuberger himself: above $n$ 73, [28].

${ }^{86}$ E Slotnick 'Who speaks for the Court? Majority opinion assignment from Taft to Burger' (1979) 23 Am J Pol Sci 60, p 63, cited in McCormick, above n 75, p 608.

${ }^{87}$ See also Paterson (2013), above n 4, p 160. 
and certainty in the law', ${ }^{88}$ while a single lead or majority opinion provides 'a coherent and certain statement of the law'. ${ }^{89}$ Arguments in favour of concurrences or multiple judgments include respect for individual opinions, ${ }^{90}$ avoidance of single judgments appearing more authoritative than they actually are and thus straitjacketing subsequent decisions, ${ }^{91}$ the value of having different viewpoints or perspectives expressed on difficult issues, ${ }^{92}$ the prompting of 'useful discussion' with academics and other judges as to how the law on a particular topic should be taken forward, ${ }^{93}$ support for judicial independence, ${ }^{94}$ acting as a reminder that litigation is not only about outcomes but also about reasoning, and demonstrating judicial engagement with the case not only by the lead opinion writer. ${ }^{95}$

In between are qualified views. For example Lord Phillips, who was generally in favour of multiple opinions, nevertheless thought that in the interpretation of criminal statutes it was necessary for the Court to speak with one voice to provide a single authoritative statement which could be applied in practice. ${ }^{96}$ Lady Hale who, according to Paterson, is generally in favour of single lead or majority opinions, nevertheless will write a concurrence where she is 'seeking to put a particular point of view on the record which it is unreasonable to expect to be included in the majority judgment'. ${ }^{97}$ Lord Neuberger in his 2012 Bailii lecture also declared himself a qualified opponent of multiple judgments, noting that self-restraint is a judicial virtue and asserting that concurrences should only be written when they really add something to the leading judgment - that is, when the topic would really benefit from judicial dialogue rather than the clarity achieved by a single lead or majority judgment. ${ }^{98}$

In fact, as James Lee has observed, concurrences may perform a variety of functions, including 'buttressing' (supporting the leading judgment), 'mediating' (delineating the common ground between the other judgments) and 'dissenting' (agreeing with the result but for what Paterson might identify as 'radically' different reasons). ${ }^{99}$ A curious example of an arguably dissenting - or certainly nonbuttressing - concurrence is Lord Brown's judgment in Yemshaw $v$ London Borough of Hounslow, ${ }^{100}$ in which, after expressing at some length his 'profound doubt' as to the interpretation of the Housing Act 1996 adopted by the other members of the Court, ${ }^{101}$ he concluded that

at the end of the day ... I do not feel sufficiently strongly as to the proper outcome of the appeal to carry these doubts to the point of dissent. I am content that the views of the majority should prevail and that the appeal should be allowed. ${ }^{102}$

Paterson found that those Supreme Court Justices who favoured multiple judgments - Lords Hope, Brown, Rodger and Mance - wrote more concurrences, while those in favour of single majority judgments (with the exception of Lord Dyson) wrote fewer concurrences. ${ }^{103}$ Extending the period covered

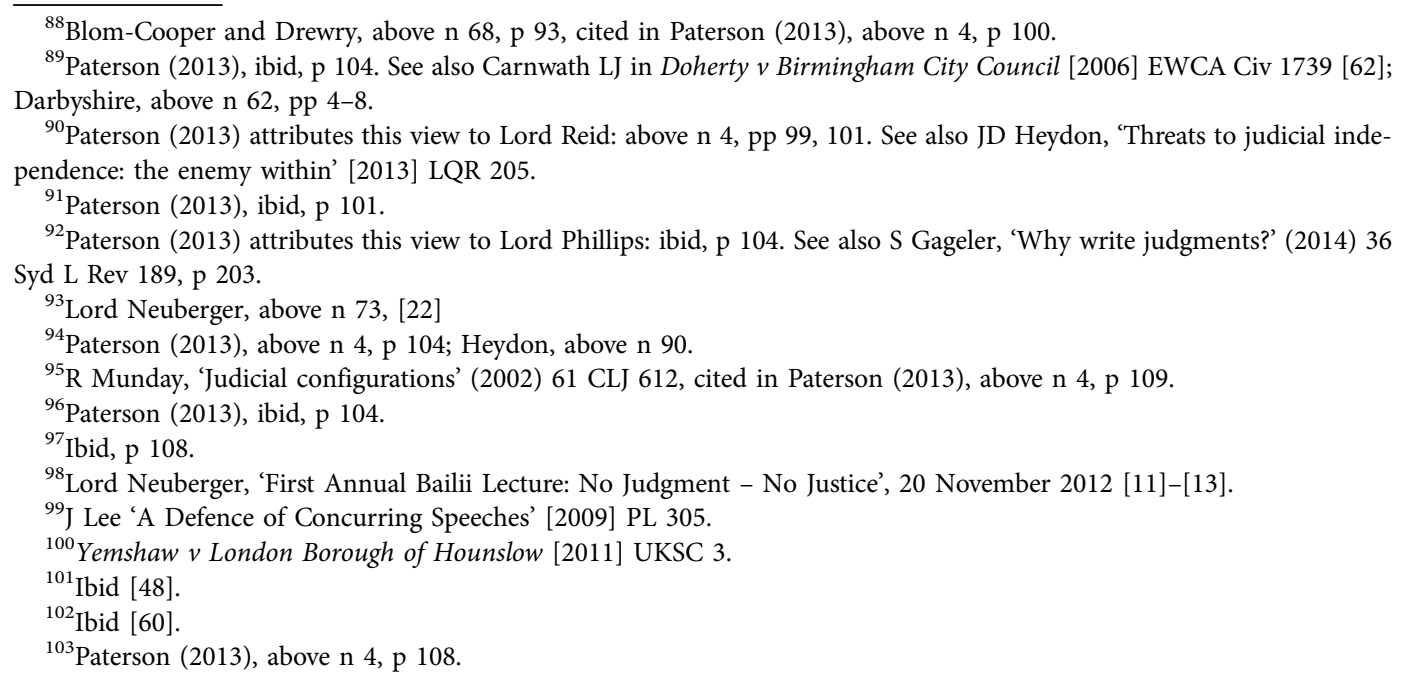


by Paterson, we found similarly that the highest proportion of concurrences was written by Lord Brown (in 38\% of his cases) followed closely by Lord Rodger (in 37\%). The next highest proportions were written by Lord Collins (in 35\%) and Lord Dyson (in 34\%). Among the Justices sitting on the Supreme Court in 2015, Lord Mance had the highest proportion of concurrences (30\%). By contrast, the lowest proportions of concurrences were written by Justices who had been appointed more recently - Lord Wilson (in 9\% of his cases) and Lord Hodge (in 10\%). It is perhaps not coincidental that the highest proportions of concurrences were written by Justices who served primarily under a President and Deputy President (Phillips-Hope) who were both pro multiple judgments and wrote many of the leading judgments themselves. Justices serving under the Neuberger-Hale leadership regime were in the opposite position, with both President and Deputy President favouring single majority judgments and more willing to share those judgments around.

Similar arguments have been advanced for and against dissenting judgments. Arguments in favour of such judgments include the value of demonstrating a different way of thinking about the issues in the case; providing an opportunity for judges (and academics and students) to debate and analyse the merits of alternative approaches; identifying the limits of the majority decision; laying the groundwork for future legal development; and strengthening judicial independence. ${ }^{104}$ Erika Rackley contends that the persuasive success of a dissenting judgment lies in its 'ability to challenge the majority's story and weaken its hold on our collective imagination'. ${ }^{105}$ It has also been observed that a dissenting opinion can have an impact in shaping the leading or majority judgment. ${ }^{106}$ For example, Paterson notes that in some cases such as $R v$ Waya, ${ }^{107}$ 'dissents are very hard-fought statements that have shifted the majority to tighter ground which will be more defensible in the future. ${ }^{108}$ In such cases, he concludes, 'the dissent has played a major and successful part in the judicial dialogue'. ${ }^{109}$

It is clear, too, that individual judges hold different views about the desirability or otherwise of dissenting. Paterson, for example, contrasts the view of Lord Kerr, who thought that if he felt the decision was wrong he should not shirk from writing a dissent, with that of Lord Wilson, who thought he should only dissent if he felt very strongly about the majority decision, at the level of being unable to live with it. ${ }^{110}$ 'Great dissenters' such as Justice Kirby on the High Court of Australia or Justice L'Heureux-Dubé on the Supreme Court of Canada dissented at rates substantially above those of their colleagues, or indeed of any UK Justice. ${ }^{11}$ Dissent is also, obviously, a relational exercise,

\footnotetext{
${ }^{104}$ C L'Heureux-Dubé 'The dissenting opinion: voice of the future?' (2000) 38 Osgoode Hall Law Journal 495, at pp 496, 508, 511-513; C Sparks 'Justice L'Heureux-Dubé: dimensions of a quintessential judicial leader' in E Sheehy (ed) Adding Feminism to Law: The Contributions of Justice Claire L'Heureux-Dubé (Toronto: Irwin Law, 2004) p 382; B Hale 'Maccabaean Lecture in jurisprudence: a minority opinion?' (2008) 154 Proceedings of the British Academy 319; Paterson (2013), above n 4, pp 111-112; MC Belleau and R Johnson 'Les femmes juges feront-elles véritablement une différence? Réflexions sur leur présence depuis vingt ans à la Cour suprême du Canada' (2005) 17 CJWL 27, at pp 30-31, 36; E Rackley 'Difference in the House of Lords' (2006) 15 Social and Legal Studies 163; E Rackley Women, Judging and the Judiciary: From Difference to Diversity (Abingdon: Routledge, 2013) chs 5 and 6.

${ }^{105}$ Rackley (2006), ibid, p 181.

${ }^{106}$ Belleau et al, above n 38, p 79.

${ }^{107} R v$ Waya [2012] UKSC 51.

${ }^{108}$ Paterson (2013), above n 4, p 110.

${ }^{109}$ Ibid.

${ }^{110}$ Ibid, p 117.

${ }^{111}$ Justice Kirby's dissent rate ranged from $26 \%$ to $48 \%$ in any given year, and on average he dissented in around one third of his cases on the High Court: Lynch, above n 34, p 516; A Lynch and G Williams 'The High Court on constitutional law: the 2003 statistics' (2004) 27 UNSWLJ 88, p 93; A Lynch and G Williams The High Court on constitutional law: the 2004 statistics' (2005) 28 UNSWLJ 14, p 19; A Lynch and G Williams 'The High Court on constitutional law: the 2005 statistics' (2006) 29 UNSWLJ 182, p 190; A Lynch and G Williams 'The High Court on constitutional law: the 2006 statistics' (2007) 30 UNSWLJ 188, p 196; A Lynch and G Williams 'The High Court on constitutional law: the 2007 statistics' (2008) 31 UNSWLJ 238, p 245; A Lynch and G Williams 'The High Court on constitutional law: the 2008 statistics' (2009) 32 UNSWLJ 181, p 188. Note, though, that this is according to Lynch and Williams' definition of 'dissent', outlined above, which would tend to inflate their figures. Justice L'Heureux-Dubé dissented in 37\% of her cases in 1984-1990, and in 32\% in 1990-1999: Belleau and Johnson, above n 104.
} 
depending on the range of views represented on the Court at any given time. ${ }^{112}$ For example, Paterson shows Lord Rodger's and Lord Brown's dissent rates going up in the transition from the House of Lords to the Supreme Court, while Lord Mance's dissent rate went down. ${ }^{13}$

According to Paterson, Lord Phillips as President saw little point in dissenting on his own, ${ }^{114}$ although it is not clear that this view was or is widely shared, since overall there were almost as many single dissents in our database (41,10\% of cases) as split decisions where two or more members of the Court dissented (52,13\% of cases). The Justices with the highest proportions of dissents during our study period were Lord Rodger (10\%) and (interestingly, given his comment to Paterson) Lord Wilson (9\%). If part concurrence-part dissents are added, those with the highest (partial) dissent rates were Lord Rodger and Lord Kerr (13\% each), followed by Lady Hale (12\%), and Lords Carnwath and Brown (11\% each). By contrast, Lord Saville never dissented on the Supreme Court and neither did Lord Dyson or Lord Hughes by the end of our study period, although Lord Hughes had one and Lord Dyson two part concurrence-part dissents. Lord Collins dissented only once.

In the majority of cases in which a Justice dissented, they wrote a separate judgment rather than simply agreeing with another member of the minority (or writing a joint dissent, which occurred in only one case, by Lords Sumption and Reed). The comparative judgment types among the Supreme Court Justices sitting on the Court at the end of the study period are set out in Table $1 .{ }^{115}$ It can be seen that the Justice who wrote the most, in whatever form, was Lord Mance by quite a large margin (writing in 59\% of his cases), followed by Lady Hale (writing in $49 \%$ of her cases). At the other end of the spectrum, Lord Wilson and Lord Hughes wrote the least (writing in only $31 \%$ and $32 \%$ of their cases, respectively). Lord Hughes also contributed fairly low proportions of leading judgments and dissents, perhaps marking him out, at least on the Supreme Court, as a 'great agree-er'. 116

\section{Specialisation}

Most Justices of the Supreme Court 'specialise' in a particular area or areas of law. ${ }^{117}$ We measured specialisation in two ways: whether a Justice was more likely to sit on some types of cases than others, and whether a Justice was more likely to write a leading judgment in some types of cases than others. In terms of individual subject areas, the areas with 20 or more cases in our database were human rights (87 cases), ${ }^{118}$ EU law (52 cases), tort (37 cases), contract/commercial (36 cases), immigration/asylum (34 cases), civil procedure (33 cases), criminal procedure (32 cases), property/land/equity (30 cases), family (29 cases), employment (26 cases) and tax (25 cases). Specialisations in these areas among the

\footnotetext{
${ }^{112}$ See eg, in relation to Justice Kirby, A Lynch 'Does the High Court disagree more often in constitutional cases? A statistical study of judgment delivery 1981-2003' (2005) 33 Fed L Rev 485, p 509; and in relation to Australian High Court Justice Dyson Heydon, Lynch and Williams 'The High Court on constitutional law: the 2012 statistics' (2013) 36 UNSWLJ 514, pp 522, 529, and A Lynch and G Williams 'The High Court on constitutional law: the 2011 statistics' (2012) 35 UNSWLJ 846, p 855 .

${ }^{113}$ Paterson (2013), above n 4, p 118.

${ }^{114}$ Ibid, p 163.

${ }^{115}$ We have focused on those Justices sitting at the end of our study period as that was the composition of the Court at the time we undertook the data analysis. Since then, Lords Toulson, Neuberger and Clarke have left the Court and Lady Black and Lords Briggs and Lloyd-Jones have been appointed.

${ }^{116}$ By contrast, Lord Hughes wrote the highest proportion of judgments in the Privy Council of all the Justices sitting at the end of our study period (in $43 \%$ of his cases), surpassed only by Lord Walker (47\%). But Lord Wilson wrote a judgment in a slightly lower than average proportion of his Privy Council cases (22\%).

${ }^{117}$ Indeed, the Information Pack for the most recent Supreme Court vacancies recognises this, noting that 'subject to the overriding principle of selection by merit, the appointment panel will wish to ensure as far as possible that there is an appropriate balance of expertise ... within the Court' (above n 2, p 4).

${ }^{118}$ For discussion of the impact of the Human Rights Act 1998 on the caseload of the House of Lords, see S Shah and T Poole 'The impact of the Human Rights Act on the House of Lords' [2009] PL 347; Poole and Shah, above n 37.
} 
Table 1. Types of judgments 2009-2015 among SCJs sitting in 2015

\begin{tabular}{lcccc}
\hline Justice & $\begin{array}{l}\text { Leading } \\
\text { judgment } \%\end{array}$ & $\begin{array}{l}\text { Written } \\
\text { concurrence } \%\end{array}$ & $\begin{array}{l}\text { Written (partial) } \\
\text { dissent } \%\end{array}$ & $\begin{array}{l}\text { Simple } \\
\text { agreement }\end{array}$ \\
\hline Lord Neuberger & 22.7 & 20.8 & 2.7 & 53.7 \\
\hline Lady Hale & 19.9 & 19.0 & 10.2 & 50.9 \\
\hline Lord Mance & 19.7 & 30.3 & 8.9 & 41.2 \\
\hline Lord Kerr & 10.2 & 17.5 & 12.6 & 59.6 \\
\hline Lord Clarke & 10.8 & 21.0 & 7.9 & 60.3 \\
\hline Lord Wilson & 16.8 & 8.8 & 5.3 & 69.0 \\
\hline Lord Sumption & 25.2 & 13.5 & 5.4 & 55.9 \\
\hline Lord Reed & 23.2 & 14.5 & 4.8 & 57.6 \\
\hline Lord Carnwath & 18.6 & 15.9 & 10.3 & 55.2 \\
\hline Lord Toulson & 25.7 & 13.6 & 2.8 & 58.1 \\
\hline Lord Hughes & 12.7 & 17.5 & 1.6 & 68.3 \\
\hline Lord Hodge & 20.6 & 10.3 & 6.8 & 62.0 \\
\hline
\end{tabular}

NOTES: * includes read Judgment of the Court; ${ }^{\star \star}$ includes participated in Judgment of the Court.

Justices sitting on the Court at the end of our study period, as measured by significantly greater likelihood of sitting on cases and writing leading judgments in that area, are set out in Table 2.

It can be seen that in 2015 each of these areas had at least one Justice who was more likely to sit on such cases, although none of the Justices was significantly more likely to write a leading judgment in the areas of human rights or criminal procedure. Lord Hope was a leading judgment writer in both of these areas, but it appears that, after his retirement, leading judgments in these two areas were spread more evenly among the Justices. Areas with the greatest numbers of Justices likely to sit consistently were criminal procedure, family law and tax. Given that human rights constituted by far the largest category of cases in the Court's caseload, the fact that two Justices (Lords Sumption and Carnwarth) were in fact significantly less likely to sit on such cases was somewhat surprising.

It is also notable that four of the Justices sitting in 2015 did not have an area of specialisation as measured by either sitting or leading judgment writing among the areas covered in Table 2. These were Lords Neuberger, Sumption, Toulson and Hughes. In terms of sitting on cases, Lord Neuberger acted as a generalist - a point clearly related to the fact that he sat on a considerably higher proportion of all cases than any of the other Justices. However, he did write leading judgments more frequently on civil procedure and property/land/equity (and also in the small number of intellectual property cases which reached the Court). Lords Sumption and Toulson did not have specialist areas in which they were more likely to write leading judgments, which appeared to be related to the fact that they were the most frequent writers of leading judgments on the Court. Lord Hughes also did not have a specialist area in which he was more likely to write leading judgments. In his case, this - together with his low proportion of leading judgments overall - may be explained by the fact that the areas in which he was more likely to sit - criminal procedure and family law - were populated by more senior subject specialists or more prolific writers of leading judgments.

In terms of our broad categories of cases (as described in the 'Methodology' section, above), the most frequently occurring were Human (229 cases), followed by Public (129 cases), Commercial (100 cases), and finally Criminal (55 cases). The results in terms of sitting and writing leading judgments among the Justices on the Court at the end of our study period are set out in Table 3 . 
Table 2. Areas of specialisation 2009-2015 among SCJs sitting in 2015

\begin{tabular}{|c|c|c|}
\hline Area & More likely to sit & More likely to write leading judgment \\
\hline Human rights & Lord Kerr & none \\
\hline EU law & Lord Mance & Lord Mance \\
\hline Tort & Lord Mance & Lord Reed \\
\hline \multirow[t]{2}{*}{ Contract/commercial } & Lord Mance & Lord Mance \\
\hline & Lord Clarke & Lord Clarke \\
\hline \multirow[t]{2}{*}{ Immigration/asylum } & Lord Wilson & Lord Kerr \\
\hline & & Lord Carnwath \\
\hline \multirow[t]{2}{*}{ Civil procedure } & Lord Clarke & Lord Neuberger \\
\hline & & Lord Clarke \\
\hline \multirow[t]{3}{*}{ Criminal procedure } & Lord Kerr & none \\
\hline & Lord Toulson & \\
\hline & Lord Hughes & \\
\hline \multirow[t]{2}{*}{ Property/land/equity } & Lord Sumption & Lord Neuberger \\
\hline & Lord Carnwath & Lord Hodge \\
\hline \multirow[t]{3}{*}{ Family } & Lady Hale & Lady Hale \\
\hline & Lord Wilson & Lord Wilson \\
\hline & Lord Hughes & \\
\hline Employment & Lady Hale & Lady Hale \\
\hline \multirow[t]{3}{*}{ Tax } & Lord Reed & Lord Reed \\
\hline & Lord Carnwath & \\
\hline & Lord Hodge & \\
\hline
\end{tabular}

On this analysis, it is interesting to note that none of the Justices were more likely than others to sit on Public law cases, although Lord Carnwath was more likely to write leading judgments in this broad area. Lords Reed and Hodge join Lord Neuberger as generalists, being neither more likely to sit nor more likely to write leading judgments in any of the broad areas. ${ }^{119}$ Lord Kerr was not specialised in any of the broad areas in terms of writing leading judgments, although here Lord Hughes did emerge as a specialist in criminal law.

More broadly still, Lady Hale's jurisprudential leadership in cases raising gender issues has been the subject of extensive discussion. ${ }^{120}$ On a preliminary classification of cases as actually or potentially raising feminist or gender issues, ${ }^{121}$ we found that Lady Hale, together with Lord Wilson, was indeed significantly more likely than other Justices both to sit on and to write the leading judgment in such cases. The conjunction with Lord Wilson in this respect is no doubt due to the substantial overlap between the 'feminist/gender' category and family law cases. This is an area of specialisation we intend to explore further in a future paper.

\footnotetext{
${ }^{119}$ This may be consistent with Brodie's claim, relying on Stevens, that Scots Law Lords (and by extension Supreme Court Justices) are distinct because of the nature of their practice at the Bar before judicial appointment: while English barristers tend to be specialists, Scots barristers are generalists (even if leaders of the profession): PH Brodie 'Scotland after 1707' in Blom-Cooper and Drewry (eds), above n 68, p 289.

${ }^{120}$ See eg Rackley (2006), (2013), above n 104; E Rackley 'Detailing judicial difference' (2009) 17 Fem L S 11.

${ }^{121}$ We defined a 'feminist' issue as one which involved women as women, or which has been the subject of feminist theory; while a 'gender' issue was one which raised an issue of difference between women and men.
} 
Table 3. Broad areas of specialisation 2009-2015 among SCJs sitting in 2015

\begin{tabular}{lll}
\hline Broad area & More likely to sit & More likely to write leading judgment \\
\hline \multirow{2}{*}{ Commercial } & Lord Mance & Lord Mance \\
\cline { 2 - 3 } & Lord Clarke & Lord Clarke \\
\cline { 2 - 3 } Criminal & Lord Sumption & Lord Sumption \\
\cline { 2 - 3 } & Lord Kerr & Lord Toulson \\
\cline { 2 - 3 } & Lord Toulson & Lord Hughes \\
\hline Human & Lord Hughes & Lady Hale \\
\cline { 2 - 3 } & Lady Hale & Lord Wilson \\
\hline \multirow{2}{*}{ Public } & Lord Kerr & Lord Mance \\
\cline { 2 - 3 } & Lord Wilson & Lord Carnwath \\
\hline
\end{tabular}

Finally, we looked at the profile of the Justices across jurisdictions. The majority of cases in our database came from England and Wales (320 cases), with 66 from Scotland and 11 from Northern Ireland. ${ }^{122}$ Lords Phillips, Neuberger, Walker, Mance and Sumption were significantly more likely to sit on cases from England and Wales than from other jurisdictions. It is expected that the Scottish judges will sit on Scottish cases, and indeed Lords Hope, Rodger and Reed were significantly more likely to sit on Scottish cases, with Lord Hodge close to significantly more likely, but with numbers too small to test accurately. Likewise, as the Northern Irish judge, Lord Kerr was significantly more likely to sit on Northern Irish cases. Interestingly, Lord Kerr and Lord Rodger demonstrated something of a Celtic specialism, with Lord Kerr also significantly more likely to sit on Scottish cases and Lord Rodger significantly more likely to sit on Northern Irish cases. Lady Hale and Lord Wilson did not specialise in any one jurisdiction but were equally likely to sit across all jurisdictions. ${ }^{123}$ In terms of presiding, Lord Hope was the chief presider in Scottish cases while he was on the Court, while the other three judicial leaders presided in roughly equal proportions of Northern Irish cases. Since the departure of Lord Hope, Lady Hale was significantly more likely to preside in Scottish cases than Lord Neuberger. ${ }^{124}$ In this sense, it could be said that more than her formal leadership colleagues, Lady Hale has acted as a judicial leader for the whole of the UK.

In summary, Lord Neuberger sat on the highest proportion of decisions issued during his time on the Court. He was a generalist in terms of sitting on cases, but with a focus in writing leading judgments on civil procedure and property/land/equity, and a jurisdictional focus on cases from England and Wales. Lord Hope wrote the highest proportion of leading judgments, with a particular focus on the areas of criminal procedure and human rights, and was (unsurprisingly) jurisdictionally specialised with regard to Scotland. Lord Kerr was the highest dissenter on the 2015 Court and was (again unsurprisingly) jurisdictionally specialised with regard to Northern Ireland. Lords Rodger and Brown wrote comparatively high proportions of both concurrences and dissents. Lord Mance was the highest concurrence writer on the 2015 Court, and also the most frequent writer altogether, specialising in commercial law, EU law and public law more generally. Lord Sumption wrote one of the highest

\footnotetext{
${ }^{122}$ In addition, we categorised five cases as coming from 'other' jurisdictions. Three of these came to the Supreme Court through the English and Welsh courts but concerned the law of the Channel Islands. Two were cases in which matters originating from England and Wales and Scotland or Northern Ireland were conjoined.

${ }^{123}$ This finding is independent of subject specialisation; that is, it is not that substantial numbers of Scottish and Northern Irish cases involved issues of family law on which Lady Hale and Lord Wilson would be expected to sit.

${ }^{124}$ Again, this is not explained by any preponderance in the subject matter of Scottish cases.
} 
proportions of leading judgments across a range of subject areas, but at the same time was significantly less likely to sit on human rights cases. Lords Toulson and Reed also wrote a high proportion of leading judgments, with different specialisation profiles. Lord Wilson had a high dissent rate but a low overall writing rate. Lord Carnwath also had a high dissent rate and was less likely to sit on human rights cases, although he did write leading judgments in public law generally. ${ }^{125}$ These patterns provide insights into the personalities and propensities of a number of the Supreme Court Justices, while demonstrating many complementary strengths on the Court. The Justices on the court at the end of our study period who did not stand out in this analysis in terms of having a particular influence or presenting a distinctive voice were Lords Clarke, Hodge and Hughes.

Lady Hale emerged as a jurisprudential leader of the Supreme Court in a number of respects. She participated in more decisions numerically than any other Justice, which translated into sitting on one of the highest proportions of cases among the Justices. She was a leading dissenter and also one of the leading writers of substantive judgments as opposed to simple agreements. She specialised in the broad category of Human cases, but was not jurisdictionally specialised, sitting equally on cases from all parts of the UK.

\section{Community leadership}

There is an increasing recognition that the visibility of the Supreme Court Justices and effective public relations play a key role in maintaining public confidence. ${ }^{126}$ The first set of viewing figures for the TV archive of Supreme Court cases (available via YouTube) indicated that it was accessed an average 10,000 times a month, with the live stream being accessed up to 20,000 times in the same period. ${ }^{127}$ The 'Brexit case'128 also shone a spotlight on the Court, with media images of the proceedings resulting in discussion and debate about the lack of gender and racial diversity on the bench (and in the courtroom more generally). ${ }^{129}$ Our focus in this section, however, is on out-of-court rather than in-court, and individual rather than collective, activities of the Justices, in order to explore the final dimension of judicial leadership.

\section{Speeches}

As noted earlier, while the 'Speeches' page of the Supreme Court website is the most comprehensive repository of the text of speeches given by the Justices, it is not complete. Unlike with overseas visits, the Supreme Court keeps no central record of the speeches given by the Justices. This means that the completeness of the collection on the website is dependent on Justices passing on their text to be uploaded. There are several reasons why they might choose not to do so - the speech may be being published elsewhere, or it may be similar to other speeches the Justice has given at an earlier

\footnotetext{
${ }^{125}$ As noted above (n 48, n 54, n 55 and accompanying text), we categorised human rights cases across topic areas, and included them within our broad 'Human' category (reflecting the substance of the rights) rather than our 'Public' category (which focuses on state actions pursuant to statutory or prerogative powers). Since each case might be coded under several topics, there would have been overlap between 'human rights' and 'public law' cases, but the former was not a subset of the latter.

${ }^{126}$ See further Cornes, above n 4, and eg the BBC4 documentary The Highest Court in the Land: Justice Makers, first shown in June 2012, which included interviews with Lords Phillips, Rodger and Kerr and Lady Hale.

${ }^{127} \mathrm{C}$ Green 'Footage of Supreme Court hearings proves an unlikely hit with the public' The Independent, 3 January 2016.

${ }^{128} R$ (on the application of Miller and another) $v$ Secretary of State for Exiting the European Union and associated references [2017] UKSC 5.

${ }^{129}$ See eg J Parkinson 'White men only? Brexit case and legal diversity' BBC News, 6 December 2010, available at http:// www.bbc.co.uk/news/uk-politics-38211701; L Smith 'As the Supreme Court mulls Brexit and Article 50, Twitter asks: Where are the women?' International Business Times, 5 December 2016, available at http://www.ibtimes.co.uk/supreme-court-mullsbrexit-article-50-twitter-asks-where-are-women-1594958; B Karemba 'The constitutional significance of the UKSC: Is it time to rethink appointments to the Apex Court again?' Judicial Diversity Initiative blog, 9 December 2016, available at http://judicialdiversityinitiative.org/category/blog/.
} 
date. ${ }^{130}$ Alternatively, Justices may be more inclined to pass on the text of their speeches if they see it as important to allow as many people as possible access to the text or if they have a formal leadership role in the Court. This may go some way to explaining why Lord Neuberger delivered just under half (49\%) of the speeches published on the website following his appointment as President of the Supreme Court. ${ }^{131}$ Indeed, the number of speeches published by Lord Neuberger (36) accounted for $26 \%$ of all published speeches during the period of our study. He was closely followed by Lady Hale, who gave $23 \%$ of the published speeches. In fact, though the number of Lady Hale's speeches increased slightly following her appointment as Deputy President, she was one of the most prolific speech givers (or at least publishers of speeches on the Court's website) throughout her time on the Court, publishing 32 speeches, easily outstripping the 13 speeches published by Lord Hope as Deputy President and fellow inaugural Supreme Court Justices, Lord Mance who published eight, Lord Kerr who published seven and Lord Clarke who published just two. Among the more recent appointees to the Court, Lord Carnwath stood out with nine published speeches. By contrast, up to the end of the 2014-2015 judicial year (and indeed up to the time of writing in March 2018) Lord Hughes had published no speeches on the Court's website.

Looking at the nature of the speeches, it is clear that the Justices are invited to speak to a wide range of people and organisations at a wide variety of venues including students and members of the public at universities (old and new), professional bodies and associations (including the Judicial College), at the Inns of Court, House of Commons, academic seminars and conferences, international courts, and public lectures. Of the 138 speeches published by the Justices during the period of our study, just under a quarter $(24 \%)$ were given overseas. Again, Lord Neuberger topped the table with the highest number of overseas speeches (eight) closely followed by Lady Hale (seven) and Lords Mance and Carnwath (five each).

As might be expected, the topics of speeches varied according to the interest and specialisms of the Justice and audience as well as current legal and political events. In 2015, for example, nine of the 18 published speeches were either explicitly on, or involved extensive discussion of, Magna Carta. On other occasions, Justices commented (with varying degrees of discretion) on the UK's membership of the EU, ${ }^{132}$ restrictions on legal aid, ${ }^{133}$ devolution, ${ }^{134}$ and the possible repeal of the Human Rights Act $1998 .{ }^{135}$ Overall, just over a third of the speeches published on the Supreme Court website fell primarily within our Human category (37\%), followed by Public (31\%), Commercial (11\%) and Criminal (4\%). In addition, $15 \%$ of speeches were primarily aimed at judicial processes or the regulation of the legal profession. Lord Neuberger, for example, often took on 'big picture' topics, particularly in relation to the role of the Supreme Court and the judiciary more generally, the process of judging and the future of the legal profession, ${ }^{136}$ a reflection no doubt of his role as President. All

\footnotetext{
${ }^{130}$ Eg Lady Hale's Fiona Woolf Lecture for the Women's Division of the Law Society on 'Women in the Judiciary' on 27 June 2014 followed a lecture with the same title at St Mary's University, Twickenham, London on 11 June 2014 (which is not online).

${ }^{131}$ Former President, Lord Phillips, in contrast published just three speeches during his time on the Court.

${ }^{132}$ Eg Lord Neuberger 'The UK Constitutional Settlement and the Role of the UK Supreme Court' Legal Wales Conference 2014, 10 October 2014; Lord Neuberger 'The British and Europe' Cambridge Freshfields Annual Law Lecture 2014,12 February 2014.

${ }^{133}$ Lady Hale 'Young Legal Aid Lawyers: Social Mobility' London South Bank University, 30 October 2013.

${ }^{134}$ Lord Hope 'The Role of the Supreme Court of the United Kingdom' The Lord Rodger of Earlsferry Memorial Lecture, 19 November 2011; Lord Neuberger 'Magna Carta: The Bible of the English Constitution or a Disgrace to the English Nation?' Guildford Cathedral, 18 June 2015.

${ }^{135}$ Lady Hale 'Georgetown Commencement Speech' 23 May 2010; Lady Hale 'Salford Human Rights Conference 2010’ 4 June 2010.

${ }^{136}$ Eg above n 73; “Judge Not, That Ye Be Not Judged”: Judging Judicial Decision-Making' FA Mann Lecture, 29 January 2015; 'Sausages and the Judicial Process: The Limits of Transparency' Annual Conference of the Supreme Court of New South Wales, Sydney, 1 August 2014; 'The Future of the Bar' Conference of the Bar Councils of Northern Ireland and Ireland, Belfast, 20 June 2014.
} 
of Lord Wilson's speeches were on an aspect of family law, ${ }^{137}$ while Lord Mance focused on technicalities of commercial law and EU matters, and Lord Sumption often took a historical perspective or approach to the topic under discussion. ${ }^{138}$ In line with her profile as 'Ms Diversity', ${ }^{139}$ Lady Hale often spoke on issues relating to equality and diversity, particularly in relation to women and children. All but one of her published speeches came within our Human category. Although only five of those speeches focused directly on diversity in the legal profession and judiciary, ${ }^{140}$ this was significantly more than her colleagues: Lords Phillips, Neuberger and Sumption each spoke once on the topic. ${ }^{141}$

Occasionally, a speech may be used by a Justice to 'set out his or her stall' in relation to a particular area of legal doctrine. Lord Sumption's 'Reflexions on the Law of Illegality' speech to the Chancery Bar Association in 2012 can be seen as an example of this. ${ }^{142}$ Although these kinds of speeches have given rise to concerns that the judge's extrajudicial comments may disqualify them from sitting on future cases, this notion has been rebutted by Lord Neuberger, who has argued that judges come to cases with open - not blank - minds, and that judges can and do change their minds. ${ }^{143}$

\section{Overseas engagements}

Overseas engagements are a reflection of the UK Supreme Court's world leadership as a court (for example, requests to know more about various administrative issues, transparency, case management and so forth), but also reflect the worldwide profile of individual Justices. It is clear that they are in demand for speaking engagements on an international level. Together they visited 44 different countries during the period of our study, that is, just under one quarter of all the countries in the world. The Justices who undertook the largest number of overseas engagements by some distance were Lord Mance (38), Lady Hale (33) and Lord Carnwath (25). Combined, they undertook over half of the 183 overseas engagements listed in the Annual Reports. When Justices' lengths of time on the Court were taken into account, Lords Carnwath and Mance came out on top (with an average of 8.3 and 6.3 overseas engagements per year, respectively), followed by Lord Phillips and Lady Hale (average 6.0 and 5.5 per year, respectively). Lady Hale's overseas engagements increased after she became Deputy President. By contrast, Lord Neuberger had an average of 3.3 overseas engagements per year and Lord Hope an average of 1.3. Lords Saville, Rodger and Brown undertook no recorded overseas engagements during their time on the Supreme Court and Lord Hodge similarly undertook no recorded overseas engagements from his appointment to the end of our study period.

The types of overseas engagements fell into several categories, including official visits (being part of a delegation, annual meetings with the European Court of Justice, meetings with Parliamentarians, the

\footnotetext{
${ }^{137}$ Adoption: Complexities Beyond the Law' Denning Society Lecture at Lincoln's Inn, 13 November 2014; 'Marriage is Made for Man, not Man for Marriage' Medico-Legal Society in Belfast, Northern Ireland, 18 February 2014; 'Out of His Shadow: The Long Struggle of Wives under English Law' The High Sheriff of Oxfordshire's Annual Law Lecture, 9 October 2012; Keynote Address at a reception hosted by Collaborative Family Law, at the Reform Club, London, 29 November 2011.

${ }^{138} \mathrm{Eg}$ 'Magna Carta Then and Now' Friends of the British Library AGM, 9 March 2015; 'The Disunited Kingdom: England, Ireland and Scotland' Denning Society, 5 November 2013.

${ }^{139}$ L Peacock 'Britain's most senior female judge, Baroness Hale: "My biggest fear ... When am I going to be found out?" The Telegraph, 18 April 2014.

${ }^{140}$ Hale, above n 130; 'Equality in the Judiciary' Kuttan Menon Memorial Lecture, 21 February 2013; 'It's a Man's World: Redressing the Balance' Norfolk Law Lecture 2012, University of East Anglia, 16 February 2012; 'Dignity' Ethel Benjamin Commemorative Address 2010, 7 May 2010.

${ }^{141}$ Lord Neuberger 'Rainbow Lecture 2014 on Diversity' House of Commons, 12 March 2014; Lord Sumption 'Home Truths about Judicial Diversity' Bar Council Law Reform Lecture, 15 November 2012; Lord Phillips 'Judicial Independence and Accountability: A View from the Supreme Court' UCL Constitution Unit, 8 February 2011.

${ }^{142}$ The defence of illegality reached the Supreme Court on no less that three separate occasions during our study period and it is well known that there are stark differences of opinion among the Justices. See further J Lee 'The judicial individuality of Lord Sumption' (2017) 40 UNSWLJ 874.

${ }^{143}$ Lord Neuberger 'The Remedial Constructive Trust - Fact or Fiction' Banking Services and Finance Law Association Conference, Queenstown, 10 August 2014 [1]-[3].
} 
Table 4. Overseas engagements $2009-2015$ by category

\begin{tabular}{|c|c|c|c|c|}
\hline Justice & Official n & Judicial n & Academic/ practitioner $\mathrm{n}$ & Total $n$ \\
\hline Lord Mance & 7 & 10 & 21 & 38 \\
\hline Lady Hale & 4 & 5 & 24 & 33 \\
\hline Lord Carnwath & 3 & 1 & 21 & 25 \\
\hline Lord Phillips & 5 & 6 & 7 & 18 \\
\hline Lord Walker & 3 & 2 & 9 & 14 \\
\hline Lord Clarke & 2 & 5 & 5 & 12 \\
\hline Lord Neuberger & 4 & 0 & 6 & 10 \\
\hline Lord Collins & 0 & 3 & 6 & 9 \\
\hline Lord Kerr & 1 & 0 & 6 & 7 \\
\hline Lord Reed & 2 & 2 & 2 & 6 \\
\hline Lord Hope & 2 & 1 & 2 & 5 \\
\hline Lord Hughes & 1 & 1 & 0 & 2 \\
\hline Lord Dyson & 0 & 1 & 0 & 1 \\
\hline Lord Wilson & 0 & 0 & 1 & 1 \\
\hline Lord Sumption & 0 & 0 & 1 & 1 \\
\hline Lord Toulson & 1 & 0 & 0 & 1 \\
\hline
\end{tabular}

Network of Presidents of Supreme Courts); judicial activities and contacts (meetings with judges, judicial training, judicial conferences, meetings to develop good practice guidelines, sitting as a judge in Hong Kong); and academic and practitioner contacts (attending and speaking at conferences, giving lectures, award of an honorary doctorate, visiting fellowships, university teaching). Table 4 shows each Justice's overseas engagements broken down by these categories.

As the Justice in charge of international judicial liaison, it is not surprising that Lord Mance had the highest number of official and judicial engagements, although he also undertook a high number of academic/practitioner engagements overseas. Lady Hale topped the rankings for overseas academic/ practitioner engagements, but undertook fewer official engagements - though no fewer than Lord Neuberger and more than Lord Hope. Several of her overseas trips were for the International Association of Women Judges, of which she was President in 2010-2012. Lord Carnwarth also had a high number of overseas academic/practitioner engagements, often involving participation in international environmental law conferences. Lord Phillips was second behind Lord Mance for official and judicial engagements overseas, but undertook fewer academic/practitioner engagements. Lord Clarke also had a relatively high number of judicial engagements. Lords Dyson, Wilson, Sumption, Toulson and Hughes were at the lowest end of all categories, having undertaken either one or no recorded overseas engagements in each category.

\section{Publications}

The publication activities of the Justices unsurprisingly mirrored to some extent their respective profiles in relation to speeches and overseas visits. The most common form of publication for all Justices was papers in journals of some description. ${ }^{144}$ Lord Neuberger and Lady Hale published the highest

\footnotetext{
${ }^{144}$ 'Papers' here includes book reviews and case comments. We have also included book chapters in edited collections in the count, although Lady Hale was the only Justice to publish in this form.
} 
number of papers during their time on the Supreme Court to the end of our study period (11 each), followed by Lord Carnwath (seven). Lord Neuberger and Lady Hale differed substantially, however, in the nature and duration of their publishing careers. Most of Lord Neuberger's publications dated from after he became President of the Supreme Court. Prior to that, he had published only two journal papers. And while the genres of his 11 Supreme Court papers were mixed, they tended towards practitioner rather than academic publications. Lady Hale, by contrast, was the most consistently prolific Justice overall, as might be expected from her academic background. But even while on the High Court, Court of Appeal and House of Lords she published 16 papers, almost all in academic journals, both generalist and specialist. Lord Carnwath was also a fairly consistently prolific author, having published eight papers while on the High Court and Court of Appeal. His Supreme Court papers were published mainly in specialist academic (environmental law) journals, while earlier papers also appeared in generalist academic journals.

The only other Justices to publish more than one or two papers while on the Supreme Court were Lord Hope (six), Lord Phillips (four), Lord Walker (four) and Lord Mance (three). Lord Hope was a frequent author before joining the Supreme Court (for example publishing 15 papers while in the House of Lords), and continued to publish after his retirement. His work was mostly published in generalist academic journals. Unlike Lord Neuberger, Lord Phillips undertook most of his published writing earlier in his career (publishing nine papers before his appointment to the House of Lords) and did less as President of the Supreme Court. Lord Walker's output was fairly consistent throughout his judicial career, both on the Supreme Court and earlier. The same was true for Lord Mance, who published mainly in generalist academic journals, plus several contributions to Lloyd's Maritime \& Commercial Law Quarterly.

Several of the Justices wrote, co-authored or edited books prior to their appointment to the Supreme Court, most notably Lord Collins, Lady Hale and Lord Carnwath, but also Lords Rodger, Mance, Reed, Toulson and Hodge. While on the Supreme Court, three of the Justices maintained general editorial roles: Lord Collins as General Editor of Dicey, Morris and Collins on the Conflict of Laws, Lady Hale as Consultant Editor on Clarke, Hall and Morrison on Children, and Lord Neuberger as Editor-in-Chief of The Civil Court Practice. However only Lady Hale had authored a book while on the Supreme Court, publishing the fifth edition of Mental Health Law in 2010. Apart from Lord Carnwath, none of the Supreme Court Justices appointed more recently during our study period distinguished themselves as notable extrajudicial writers. While Lord Sumption was a well-known historian prior to his appointment to the Court and he continued to publish historical texts, his legal writing was and remained more limited.

In summary, the publicly visible work of community leadership among the Justices of the Supreme Court appears to have been concentrated in only a few hands: those of Lady Hale, Lord Neuberger, Lord Mance, Lord Carnwath and Lord Phillips. Lord Phillips' community leadership was focused on overseas engagements. He undertook a relatively high proportion of such engagements during his time on the Court, but published relatively few speeches and journal papers. Lord Neuberger published a large number of speeches and papers after he became President of the Supreme Court, but was not so prominent in relation to overseas engagements. Conversely, Lord Mance led the field in overseas engagements, not only by virtue of his international judicial liaison role, but also via academic and practitioner engagements, while his speech and paper publication rates were more modest. Lord Carnwath and Lady Hale were the only all-rounders. Lord Carnwath published substantial numbers of speeches and papers, particularly in the specialist area of environmental and planning law, and undertook a substantial number of overseas engagements. Lady Hale exemplified the maxim, 'If you want something done, ask a busy woman'. Her workload in terms of speeches and overseas engagements increased after she became Deputy President, but even before that, she was a leader in terms of published speeches, published papers and books, and overseas engagements, especially invited lectures. This level of community outreach was not counterbalanced, for example, by sitting on fewer cases. As we have seen, Lady Hale sat on 
the highest proportion of Supreme Court cases after Lord Neuberger, 10\% more than most of her judicial colleagues. ${ }^{145}$

\section{Conclusion}

As the privileged incumbents of the highest judicial office in the UK, one might expect all of the Justices of the Supreme Court to be judicial leaders of some kind. The various functions performed by the Court - its internal governance, its decision making and its symbolic position - create demands for administrative, jurisprudential and community leadership. Rather than attempting, as most previous literature has done, to identify 'the' supreme of the Supreme Court Justices in purely jurisprudential terms, this paper has explored the various dimensions of judicial leadership in order to consider in what ways and to what extent Supreme Court Justices can be publicly observed to be acting as leaders. In relation to the Court's formal leaders during our study period - Lords Phillips, Hope and Neuberger and Lady Hale as Deputy President - the question has been about what difference they made in those formal roles. In relation to the other Justices (including Lady Hale before she became Deputy President), the question has been about what difference they made by virtue of their membership of the Supreme Court. The answers to these questions have obvious implications for the future of the Court, and for future appointments to the Court and to formal leadership roles.

Our analysis suggests that there are a number of ways of being a judicial leader. Formal leadership roles on the Supreme Court do translate into both jurisprudential and community leadership. Jurisprudentially, formal leaders tend to sit on high proportions of cases, and the presiding Justice who is almost always the President or Deputy President - is more likely to write the leading judgment in a case and more likely to have their opinion of the outcome of the case prevail (that is, they are less likely to be in dissent). Moreover, their ability to choose who writes the leading judgment (in their stead) enables them to influence the jurisprudential direction of the Court by proxy. In this context, the Neuberger-Hale leadership regime gave more leading judgment writing opportunities to other Justices than did the Phillips-Hope leadership regime. In relation to community leadership, the President and Deputy President have tended to be prominent in at least one (although not necessarily all) of the areas of giving speeches, publishing journal papers, and overseas engagements. The different jurisprudential and community leadership profiles of Lord Phillips and Lord Neuberger illustrate that there are different ways of being President of the Supreme Court, although at least some willingness to engage in community outreach activities of some kind seems to be an essential criterion.

Jurisprudential and community leadership roles may also be assumed by individual Justices regardless of any formal leadership responsibilities. In this respect, our analysis suggests that, while many of the Justices have taken on some kind of observable jurisprudential leadership role, few have combined it with an observable community leadership role, and some have done neither. The two Justices outside the Court's formal leadership positions who evidenced both jurisprudential and community leadership were Lords Mance and Carnwath. The group of Justices who may be seen as jurisprudential but not community leaders consists of Lords Hope, Kerr, Rodger, Brown, Sumption, Toulson and Reed. On the measures of leadership used in this paper, Lords Clarke, Wilson, Hodge and Hughes made relatively modest or minimal contributions, even taking into account the recent arrival of the latter two Justices on the Court.

Lady Hale emerged as a clear leader in all three of the public dimensions of leadership examined. Like Lords Mance and Carnwath, she was a jurisprudential and community leader before becoming Deputy President, and as Deputy President she extended her contributions in these areas, as well as performing her administrative role. Most notably, she participated in more Supreme Court decisions numerically than any other Justice, when she wrote the leading judgment she was most likely

\footnotetext{
${ }^{145}$ This remains true even when Privy Council cases are taken into account. Among the four Justices in our study who joined the Supreme Court at its inception, Lady Hale sat on a total of 285 Supreme Court and Privy Council cases, compared to Lord Clarke's 269, Lord Mance's 267 and Lord Kerr's 257.
} 
to produce unanimity, and she sat equally on cases from all parts of the UK. In addition, she was a leader in all three forms of community outreach discussed: published speeches, published papers and books, and overseas engagements, especially invited lectures.

As well as identifying the forms of leadership evidenced by individual Justices, these findings can also be viewed from the perspective of the Supreme Court as an institution. ${ }^{146}$ The Court has already seen substantial changes with the retirements of Lords Toulson, Clarke and Neuberger, and will see a further three retirements - Lords Mance, Sumption and Hughes - by the end of 2018. Not only has this already deprived the Court of one of its formal leaders, it will also deprive it of several of its jurisprudential leaders and one of its pre-eminent community leaders. These are factors which, we argue, ought to be taken into account in the appointment process for new Supreme Court Justices, in a way that goes beyond mere subject matter or jurisdictional specialisation. Simply appointing a Chancery judge $^{147}$ or a Scottish or Northern Irish judge for the sake of subject matter or jurisdictional representation $^{148}$ ignores other important dimensions of judicial leadership. While, as noted at the beginning of this paper, the current selection process for the Supreme Court requires applicants to demonstrate an appreciation of the developing nature of the constitution and law, and a willingness to participate in the wider representational role of a Supreme Court Justice, we would suggest that the requirement to demonstrate a capacity to exercise some form of jurisprudential and community leadership should be much more clearly articulated in the Supreme Court selection process.

At the same time, we do not advocate that eligibility for Supreme Court appointment should be confined to those who have held previous senior judicial administrative or managerial roles. This would significantly narrow the pool (both in terms of numbers and diversity), and the evidence from the current Supreme Court is that having held such office is not necessarily a predictor of an active leadership role on the Court. Indeed, some of the Court's notable leaders (such as Lord Mance and Lady Hale) did not have this kind of prior experience. Rather, leadership qualities and the capacity to exercise leadership should be assessed much more broadly.

Consideration should also be given to the intersection between the demands of jurisprudential and community leadership and judicial diversity. In relation to jurisprudential leadership, bringing different life experience and a different point of view to the Court is likely to enhance the development of the law. ${ }^{149}$ In relation to community leadership, judges who are not white males from privileged educational backgrounds would enhance the democratic representativeness of the Court and could offer symbolic leadership as well as practical mentorship to a wider section of the legal profession. ${ }^{150}$ More

\footnotetext{
${ }^{146}$ See TT Arvind and L Stirton 'Legal ideology, legal doctrine and the UK's top judges' [2016] PL 418, pp 430-433, who note the importance of institutional design and the need to achieve 'an appropriate balance of attitudes and dispositions' on the Court.

${ }^{147} \mathrm{Cf}$ eg Joshua Rozenberg's suggestion that Lord Toulson should be replaced by a Chancery lawyer (despite the fact that Toulson was a common lawyer): 'Warming the bench' Law Society Gazette, 7 March 2016.

${ }^{148}$ Arguably, Lady Hale's and Lord Wilson's performance as jurisdictional generalists calls into question the need for separate jurisdictional representation among the permanent members of the Court, with the possibility of drafting in jurisdictional specialists as temporary Justices for particular hearings when necessary. Nevertheless, jurisdictional representation is the one form of quota/affirmative action provided for in the CRA. The point remains, however, that whichever Scottish or Northern Irish candidates are chosen, they ought to be able to demonstrate and be willing to take on some other form of judicial leadership.

${ }^{149}$ There is a substantial literature on this point, eg Hale, above n 104; Rackley, above n 104; R Hunter 'More than just a different face: judicial diversity and decision-making' (2015) 6 CLP 119; T Etherton 'Liberty, the archetype and diversity: a philosophy of judging' [2010] PL 727; Sheehy, above n 104; Belleau and Johnson, above n 104.

${ }^{150}$ Some examples from the substantial literature on this point include: Lord Neuberger 'The Role of the Supreme Court Seven Years on - Lessons Learnt' Bar Council Law Reform Lecture 2016, 21 November 2016; K Malleson 'Justifying gender equality on the bench: why difference won't do' (2003) 11 FLS 1; SA Ifill 'Judging the judges: racial diversity, impartiality and representation on State Trial Courts' (1997-1998) 39 Boston College L Rev 95; RV McGregor 'Sandra Day O'Connor' (2006) 119 HLR 1245; L Moran, 'Judicial diversity and the challenge of sexuality: some preliminary findings' (2006) 28 Syd L Rev 565; S Kenney Gender and Justice: Why Women in the Judiciary Really Matter (New York: Routledge, 2013); R Cowan 'Do women on South Africa's courts make a difference?' in U Schultz and G Shaw (eds) Gender and Judging (Oxford: Hart, 2013) 117.
} 
generally, given women's observed greater facility for multitasking ${ }^{151}$ (as exemplified by Lady Hale), and the equally observed need for non-traditional judges to prove themselves by working twice as hard as their more entitled colleagues, ${ }^{152}$ the criteria of diversity and leadership activity may prove to be entirely complementary.

In short, Lady Hale, Lord Carnwath and Lord Reed need to be joined by a diverse group of new Justices who are capable of and prepared to shoulder the burdens of administrative, jurisprudential and community leadership, and thus to play their part in a new era of judicial leadership both on and by the UK Supreme Court.

\footnotetext{
${ }^{151}$ See eg A Zaiceva and K Zimmerman 'Do ethnic minorities "stretch" their time? UK household evidence on multitasking' (2011) 9 Review of Economics of the Household 181 (inter alia, reviewing the literature on gender and multitasking). See also S Roach Anleu and K Mack 'Judicial performance and experiences of judicial work: findings from socio-legal research' (2014) 4 Onati Socio-Legal Series 1015, pp 1032-1034.

${ }^{152}$ See eg R Hunter 'The high price of success: the backlash against women judges in Australia' in E Sheehy and S McIntyre (eds) Calling for Change: Women, Law and the Legal Profession (Ottawa: Ottawa University Press, 2006) 281, pp 282-283; M Thornton Dissonance and Distrust: Women in the Legal Profession (Melbourne: Oxford University Press, 1996) pp 203-204; U Schultz,"'I was noticed and I was asked ..." Women's careers in the judiciary: results of an empirical study for the Ministry of Justice in Northrhine-Westfalia, Germany' in U Schultz and G Shaw (eds) Gender and Judging (Oxford: Hart, 2013 ) p 158. See also H Sommerlad 'Let history judge? Gender, race, class and performative identity: a study of women judges in England and Wales' in U Schultz and G Shaw (eds) Gender and Judging (Oxford: Hart, 2013) 355.
}

Cite this article: Hunter R, Rackley E (2018). Judicial leadership on the UK Supreme Court. Legal Studies 38, $191-220$. https://doi.org/10.1017/lst.2017.19 